\title{
İşe Adanmışlık ve Örgütsel Özdeşleşme İlişkisinin Performans Algısına Etkisi Üzerine Bir Araşttrma*
}

\section{A Research to Determine the Effects of Work Engagement and Organizational Identification Relations on The Performance Perception}

\section{Kadir Aktaş $^{1}$, , Bünyamin Akdemir $^{2}$ (i)}

\section{Öz}

Bu çalışmanın temel amacı, işgörenlerin işe adanmışlık düzeyleri ve örgütsel özdeşleşme ilişkisinin performans algısına etkilerini belirlemektir. Araştırma amacı doğrultusunda, Ankara Büyükşehir Belediyesinden 555 ve Eskişehir Odunpazarı Belediyesi çalışanlarından 92, Ankara'da AFAD Başkanlığı Merkez Binasında çalışanlardan 98 ve İstanbul'da ise ASis A.Ş. çalışanlarından 98 kathlımcı olmak üzere toplam 843 kişiden anket aracılığıyla elde edilen veriler "faktör analizi, korelasyon analizi ve Yapısal Eşitlik Modellemesi analizleri" yöntemiyle değerlendirilmiştir.

Araştırma sonucunda elde edilen bulgulara göre; işe adanma, örgütsel özdeşleşme ve performans algısı değişkenleri arasında istatistiksel olarak anlamlı ilişkilerin bulunduğu tespit edilmiş ve araştırma sonucuna ulaşılmıştır. Araştırma modelindeki bağımsız değişkenlerin (işe adanma, örgütsel özdeşleşme) bağımlı değişkenleri (performans) etkileme düzeyleri ile bağımsız ve bağımlı değişkenlerin kendi aralarındaki etkileşim düzeyleri açıklanmıştır.

Anahtar Kelimeler

İşe Adanmışlık, Özdeşleşme, Örgütsel özdeşleşme, Performans, Performans algısı

\begin{abstract}
The main purpose of this study is to determine the relationship of employee engagement and organizational identification's effects on their performance. For the purpose of the research, the data obtained from questionnaires filled out by total 843 employees, working in the Greater Municipality of Ankara 555, in the
\end{abstract}

\footnotetext{
* Bu araştırma Aktaş K., (2019) “iş̧örenlerin Adanmişlik Düzeyi ve Örgütsel Özdeşleşme illişkisinin Performans Algısına Etkisini Belirlemeye Yönelik Bir Araştırma” isimli (Yayımlanmamış) Doktora Tezinden alınmıştır.

1 Sorumlu Yazar: Kadir Aktaş (Dr.), Milli Savunma Bakanlığı Lojistik Daire Başkanlığı, Ankara, Türkiye.

E-posta: aktas0072@hotmail.com ORCID: 0000-0002-1307-5402

2 Bünyamin Akdemir (Prof. Dr.), İnönü Üniversitesi, İktisadi ve İdari Bilimler Fakültesi, İşletme Bölümü, Malatya, Türkiye. E-posta: bunyamin.akdemir@inonu.edu.tr ORCID: 0000-0003-2285-5643
}

Attf: Aktas, K. ve Akdemir, B. (2019). İşgörenlerin adanmışlık düzeyi ve örgütsel özdeşleşme ilişkisinin performans algısına etkisini belirlemeye yönelik bir araştırma. Sosyal Siyaset Konferansları Dergisi, 77: 307-348. https://doi.org/10.26650/jspc.2019.77.0042 
Eskişehir Odunpazarı Municipality 92, in the Ankara Prime Ministry of AFAD 98 and in the İstanbul ASis Corporation 98 were evaluated by means of factor, correlation and SEM analysis.

According to the findings obtained as a result of the research; statistically significant correlations are found among employee engagement, organizational identification and performance perception variables, and the research results have been reached. The level of influence of independent variables (employee engagement, organizational identification) on dependent variables (performance perception), and the level of interaction between independent and dependent variables in the research model are explained.

\section{Keywords}

Work engagement, Identification, Organizational identification, Performance, Performance perception 


\section{Extended Summary}

In today's increasingly competitive environment, it is becoming more and more difficult to ensure the continuity of trained and qualified personnel in the organization, as well as providing qualified personnel or providing additional qualifications for the personnel. One of the most important reasons for this is the ability to communicate very quickly all over the world, thanks to the developing communication technologies and being informed instantly of all kinds of opportunities in the world.

In this competitive environment, qualified personnel turn to new organizations, new cities, countries and continents, by spreading towards the opportunities offered to them. In this case, in addition to providing qualified personnel or training to personnel for qualification, it has become essential for organizations to take measures and develop methods, in order to ensure that these personnel are identified and dedicated to their work and organisations.

It is evident in the results of research that employing highly qualified, resourceful, intelligent, strong, durable and diligent employees without dedication to organizations does not provide a great advantage. For example, research in the United States has estimated that the annual cost of economic loss from insufficient or never dedicated staff is around \$250 to350 million. This figure corresponds to approximately $2 \%$ of the US GNP (Gross National Product) at that time (Attridge, 2009: 387). If so, this issue is worth considering.

For those reasons, it is mandatory to acquire and train qualified personnel, and to take measures and develop new methods to ensure that employees identify with their organizations and are dedicated to their work. In the literature survey within this framework, it is observed that in the last 10 years, there has been an intensive study of these concepts. Although there are some researches, especially on the "employee engagement and performance perception" and "organizational identification and performance perception interactions", that there has not been any research on "the influence of relations between employee engagement and organizational identification on the performance perception", has shown the need to research this subject. Therefore, it is thought that this research will contribute to fill an emptiness in the area.

In light of the explanations above, in this study, concepts of employee engagement, organizational identification and performance perception are 
examined theoretically in the first, second and third sections. In the fourth section of the study, how the research is conducted and which method is used to analyzing the data are mentioned. In the last section, there are general evaluations and the results of research obtained with the aim of the study and discussions.

In this context, the main purpose of this study is to determine the relationship of employee engagement and organizational identification's effects on their performance. For the purpose of the research, the data obtained from questionnaires filled out by total 843 employees, working in the Greater Municipality of Ankara 555, in the Eskişehir Odunpazarı Municipality 92, in the Ankara Prime Ministry of AFAD 98 and in the İstanbul ASİS Corporation 98 were evaluated by means of factor, correlation and SEM analysis.

According to the findings obtained as a result of the research; statistically significant correlations are found among employee engagement, organizational identification and performance perception variables and the research results have been reached. The level of influence of independent variables (employee engagement, organizational identification) on dependent variables (performance perception), and the level of interaction between independent and dependent variables in the research model are explained. 


\section{İşe Adanmışlık ve Örgütsel Özdeşleşme İlişkisinin Performans Algısına Etkisi Üzerine Bir Araştırma}

Günümüzde artan rekabet ortamında, nitelikli personeli temin etmek veya personele ilave nitelikler kazandırmak kadar, yetişmiş ve kalifiye personelin örgütte devamlılığını sağlamak da giderek zorlaşmaktadır. Bunun en önemli nedenlerinden biri de gelişen iletişim teknolojisi sayesinde, dünyanın her yeriyle çok hızlı iletişim kurabilme imkanının sunulması ve her türlü firsattan anında haberdar olunmasıdır. Nitelikli personel, bu rekabet ortamında, kendilerine sunulan firsat ve imkanlara doğru yönelerek, yeni örgütlere, yeni şehirlere, ülkelere ve kıtalara açılmaktadır. Bu durumda nitelikli ve kalifiye personeli temin etmek ve yetiştirmenin yanında, örgütlerin bu personelin örgütleriyle özdeşleşmelerini ve işlerine adanmalarını sağlayacak yönde tedbirler alması ve yöntemler geliştirmesi elzem hale gelmiştir.

Örgütler için adanmışlık tutumu olmaksızın çok nitelikli, becerikli, zeki, kuvvetli, dayanıklı ve gayretli işgörenleri istihdam etmenin, çok büyük bir avantaj sağlamadığı bariz bir biçimde araştırmalarda görülmektedir. Örneğin, Rath ve Conchie'nin 2009 yılındaki araştırmalarına göre; ABD'de yeterince veya hiç adanmamış personelden kaynaklı ekonomik kaybın yıllık maliyetinin 250-350 milyon dolar civarında olduğu hesaplamıştır. Öyle ki bu rakam o dönemde ülkenin GSMH'nin yaklaşık \%2'sine denk gelmektedir (Attridge, 2009: 387). Öyleyse bu konu incelemeye değer bir konu olarak karşımıza çıkmaktadır.

Günümüz işletmeleri açısından hayati öneme sahip olan diğer bir kavram, örgütsel özdeşleşmedir. Örgütsel özdeşleşme kavramı, "kişinin, kendisini birlikte tanımladığı örgüte ait ya da örgütle bir bütün olarak hissetmesi ve örgütün başarı ile başarısızlığını kendi başarı ve başarısızlığı olarak algılaması durumu" olarak ifade edilebilir (Cüce vd., 2013: 7). Dış çevre koşullarında ortaya çıkan değişim ve gelişmeler, çalışanlar ile örgüt arasındaki psikolojik ilişkinin önemini daha da artırmaktadır. Diğer bir deyişle, bugün örgütler işgörenlerden iş yerini sevme, sadık olma ve örgüte bağlı olma gibi birtakım duyguların ötesine geçmelerini beklemekte; örgütü bireysel kimlikleri ile özdeşleştirecek şekilde benimsemelerini istemektedir. Bu nedenle örgütsel özdeşleşme konusu günümüz örgütleri ve işletmeleri açısından anlaşılması gereken bir kavram olarak karşımıza çıkmaktadır (İşcan, 2006: 161). 
Bu bağlamda makalenin temel amacı, işgörenlerin işe adanmışlık düzeyleri ve örgütsel özdeşleşme ilişkisinin, işgörenlerin performans algısına etkilerini araştırmaktır. Bu maksatla makalede sırasıyla birinci bölümde işe adanma, ikinci bölümde örgütsel özdeşleşme, üçüncü bölümde performans algısı kavramları teorik olarak incelenmiştir. Makalenin dördüncü bölümü olan "araştırma" bölümünde ise araştırmanın amacı doğrultusunda, farklı kurum ve kuruluşlardan toplam 843 kişiden anket aracıllğıyla elde edilen veriler çeşitli istatistiki yöntemler kullanılarak analiz edilmiş ve elde edilen sonuçlar tablolara dönüştürülerek değerlendirilmiştir. Son bölüm olan "genel değerlendirme ve sonuçlar" bölümünde ise araştırmanın sonuçları ile araştırmanın sonuçları ve uygulayıcılara öneriler ifade edilerek makale tamamlanmıştır.

\section{İşe Adanma Kavramı}

Adanmışl1k, "bir kişinin bütün gücünü belli hedefe teksif etmesi, o hedef doğrultusunda gayretlerini yoğunlaştırması” anlamındadır. Örgütsel adanmışlık ise; "işgörenin örgütün hedeflerini benimsemesi ve bütün gayretlerini örgüt hedefleri doğrultusunda yoğunlaştırması” anlamındadır. Örgütsel adanmışlığın zirvesinin “örgütsel fanatiklik ya da fedailik” olduğu söylenebilir (Koçel, 2014: 534).

Yönetim alanında işgören adanmışlığı konusunda ilk temel çalışmanın Kahn'ın (1990) "Personelin İşe Adanması ve Adanmamasında Psiklojik Durumlar" makalesi olarak görülmektedir (Saks and Gruman, 2014: 156). İşe adanmışlık çalışmalarıyla ilgi olarak yapılan incelemede, işe adanmışlık boyutlarına dair ilk tasnif Kahn (1990) tarafından yapılmış olup bunlar "özellik adanmışlığı, durumsal adanmışlık ve davranışsal adanmışlık” olarak ifade edilmiş ancak detaylandırılmamıştır (Schaufeli and Bakker, 2010: 19-22).

Kahn'a göre işe adanmışlık; örgüt üyelerini (kişilikleriyle birlikte) iş rollerine bağlayan donanımlardır ve işe adanmış bireyler görevlerinde fiziksel, bilişsel ve duygusal olarak gayret gösterirler (Kahn, 1990:700).

Bu alanda çalışma yapmış diğer bir araştırmacı olan Leiter ve Maslach'a göre işe adanma kavramı; işgörenin işle ilgili faaliyetlere, mesleki verimlilik hislerini yükseltici, enerji dolu katılımını ifade etmektedir. Bazı araştırmacılar, tükenmişliğin, işe adanmanın tam karşıtı olduğunu ileri sürerek işgörenlerin işe adanma düzeyini saptamak için tükenmişlik düzeyinin ölçümlenmesinin yeterli olduğunu savunmaktadırlar (Maslach and Leiter, 2008: 498-499). 
İşe adanmışlık konusunda bir çok araştırması bulunan Schaufeli ve arkadaşlarına göre işe adanma kavramı; işgörenin işinde sergilediği enerjiklik, adanma ve içselleştirmeden müteşekkil, olumlu ve memnun bir ruh hali olarak tanımlanmaktadır (Schaufeli et al., 2006:701-702).

Bu kapsamda Schaufeli ve arkadaşları işe adanmışlığı enerjik olmak (dinçlik), adanmışlık (güçlü bağl1lık) ve içselleştirme (benimseme) olarak üç boyutta ele almışlardır. Araştırma sürecinde makalemizde de bu boyutlar kullanılmıştır (González-Romá et al, 2006:166). İşe adanmışlık tutumunun alt boyutlarını kısaca şöyle açıklayabiliriz;

a. Enerjik olmak (Dinçlik): Orjinalinde İngilizce “vigor” olarak kullanılan ve dilimizde "enerjik ve dinç olmak" olarak çevrilen bu kavram; yüksek seviyeli enerji, çalışırken mantıki esneklik, işgörenin işine isteyerek gayret sarf etmesinden ve zorluklar karşısında metanetinden oluşan bir özellik olarak ifade edilmektedir (Schaufeli vd., 2006:702).

b. İşe adanmak (Güçlü bağlılık): Orijinal kaynağında "dedication” olarak ifade edilen bu kavram, "işe adanma, birinin işine güçlü bir şekilde bağlanmasını ve işini önemsediğini, coşkuyu, ilhamı, gururu ve meydan okuma hislerini yaşamayı işaret etmektedir (Schaufeli vd., 2006:702).

c. İlgilenmek (Benimsemek): İngilizce "involvement” olarak ifade edilen ve dilimizde "katılım, ilgilenme ve benimseme" olarak kullanılan bu kavram; bir işgörenin tamamen işine yoğunlaşması ve mutlulukla işine dalmasını ifade etmektedir (Schaufeli ve Bakker, 2010:11). Çalışma esnada zamanın hızla akıp geçmesi ve kendini işinden ayırmakta zorluk çekmesidir. Kısaca yaptığı işin kişinin hobisi haline gelmesi durumudur (Aybas, 2014: 16).

\section{Örgütsel Özdeşleşme Kavramı}

Akademik olarak özdeşleşme kavramı; bireyin kendisini başka kişi veya grupla aynılaştırması ve onlarda meydana gelen değişiklikleri kendisine gelen değişiklik gibi hissetmesi durumudur (Koçel, 2011: 534).

Lee (1971) örgütsel bağl1lıkla ilişkili olarak gördüğü örgütsel özdeşleşmeyi "bir dereceye kadar ait olma veya sadakat" olarak tanımlamıştır (Akt. Buchanan, 1974:533). 
Örgütsel özdeşleşme, bireylerin kendilerini özel bir grubun üyesi olarak algıladıkları sosyal kimlik teorisinin özel bir şeklidir. Bireyler bir grupla özdeşleştiklerinde, bu gruplara ait olduklarını düşünmektedirler. Bundan dolayı, bireyin benlik kavram1, örgütün genel karakterine benzerlik göstermektedir. Örgütsel özdeşleşme, birey ve örgüt arasında bilişsel bir bağlantıyı şekillendirmektedir (Chen et al., 2015;11-12).

Literatür incelemesinde örgütsel özdeşleşme ile ilgili ilk çalışmanın 1943 yılında Edward Tolman tarafından yapıldığı görülmektedir. Tolman yaptığı bu çalışmasında birbirlerinden oldukça farklı olmasına rağmen, birbiri ile ilişkili üç özdeşleşme türünden bahsetmiştir (Köse, 2009: 6):

i. Bir kişinin kendisinden daha olgun (güvendiği veya kıskandığı ) birisini taklit etmeye çalışması ya da rol model olarak alması,

ii. Bir bireyin, kendini ait olarak hissettiği herhangi bir gruba bağlı olması,

iii. Özdeşleşmenin, birey tarafından harekete sevk edici unsur olması şeklinde ifade edilmiştir.

Örgütsel özdeşleşmenin boyutlarının geliştirilmesine ve ölçülmesine yönelik ilk deneysel çalışma 1969 yılında Brown tarafından yapılmıştır. Brown örgütsel özdeşleşmeyi; örgüt cazibesi, örgütsel ve bireysel amaçların uyumu, örgüte sadakat, bireyin kimliğini tanımlamada örgüt üyeliğini referans olmak üzere dört boyut altında ifade etmiştir. Lee $(1969,1971)$ çalışmalarında örgütsel özdeşleşmenin "üyelik, sadakat ve ortak özellikler" olmak üzere üç boyutlu bir özellik taşıdığını belirtmiştir (Kanten, 2008:171).

Van Dick ve arkadaşları örgütsel özdeşleşmeyi bilişsel, duygusal, değerlendirme ve davranışsal olarak dört boyutta ele almıştır (Dick et al., 2005:192). Aslında bu boyutlandırma örgütsel özdeşleşmenin de temelini oluşturan sosyal kimlik kavramının boyutlandırılmasıyla paralellik etmektedir. Bu boyutları aşağıdaki gibi açıklayabiliriz;

a. Bilişsel boyut: Belli bir gruba üye olduğunun şuurunda olmayı ifade etmektedir. Birey bir kez kendisinin örgüt içerisinde bir sınıflandırmaya dahil olduğunu algıladıktan ve kabul ettikten sonra, diğer üç boyut devreye girmektedir (Dirin, 2014:58). 
b. Duygusal boyut: Bir gruba olan duygusal bağl1lı̆̆ ifade etmektedir. Grubun bir parçası olmaktan dolayı duyulan gururla ilgili olmakla birlikte, bireyin grubu ile ilgili pozitif imaj oluşturmasında veya pozitif bir sosyal kimlik geliştirmesinde önemlidir (Özdemir, 2007: 69).

c. Değerlendirme boyutu: Hem içeriden, hem dişarıdan yapılan değerlendirmelerde örgüte atfedilen kıymet olarak ifade edilmektedir (Özdemir, 2007: 69).

d. Davranışsal boyut: Genel bir ifadeyle örgütsel özdeşleşmişliği en iyi ifade eden olgular, pozitif örgütsel davranışlardır. Bazı araştırmacılar ilk boyut olan bilişsel boyutun bireyde oluşmasından sonra, diğer boyutların ortaya çıkacağını savunmuşlardır. Bu üç boyutların hangi sırayla çıkacağı konusunda bir mutabakat olmamakla birlikte, birbirleri ile ilişkili oldukları kabul edilmiştir. Bu kapsamda davranışsal boyut, genel olarak bireyin örgütün ritüellerine katılmasını ve kendinden beklenen yönde davranışlar sergilemesini ifade etmektedir (İşcan ve Karabey, 2009: 42).

\section{Performans Algısı Kavramı}

Performans kelimesinin TDK sözlügünde anlamı "başarım" olarak verilmektedir (TDK, 2017). Performans terimi köken olarak İngilizce bir kelime olup; yapma, icra etme, başarı gibi anlamları vardır.

Araştırmamızda değişkenlerden biride işgörenlerin yaptıkları işe yönelik performans algısıdır. Algılamak; duyu organlarına çarpan harici ikazların farkına varılması ve değerlendirmesi sürecinin bütünü olarak ifade edilmektedir (Barlı, 2010: 105).

Performans, bir işi yapan bireyin/örgütün amaçlanan hedefe ulaş1lıp ulaşılmadığını ifade için kullanılan bir kavramdır (Bilgin vd., 2011: 149).

Başka bir araştırmacıya göre performans; görev kapsamında standartları karşılayacak şekilde görevin icrası ve amacın gerçekleştirilmesi maksadıyla ortaya konan mal, hizmet veya emektir (Helvac1, 2002: 156).

Bernadin (1995) performansın iş sonuçları, örgütün stratejik hedefleri, müşteri memnuniyeti ve ekonomik sonuçlarla güçlü bir şekilde bağlantı içinde olduğuna vurgu yapmıştır (Öztürk, 2006: 12). 
Performans alg1s1 ise "özdeğerlendirmeye dayalı bireysel performans" olarak da ifade edilmiştir (Aktaş ve Şimşek, 2014: 31).

$\mathrm{Bu}$ araştırmada kullanılan performans algısından kastedilen; işgörenin hissettiği performansın kendisi tarafından değerlendirilmesidir. Diğer bir deyişle, işgöreninin kendi kendini değerlendirmesi veya işgörenin özdeğerlendirmesi olarak ifade edilebilir.

\section{Araştırma}

\section{Araştırmanın Amacı}

Araştırmanın temel amacı, modern sonrası olarak nitelendirilen kavramlardan olan "İşe adanmışlık” ve “örgütsel özdeşleşme” kavramlarını incelemek, bu kavramların birbirleri ile ilişkisini ve bu ilişkinin performans algısına olan etkisini incelemektir. Yapılan literatür taramasında "işe adanmışlık ve performans" ile "örgütsel özdeşleşme ve performans" etkileşimi hakkında araştırmalar bulunmasına rağmen, "işe adanmışlık ve örgütsel özdeşleşme ilişkisinin performans algısına etkisini” inceleyen bir çalışmaya rastlanılmamıştır. $\mathrm{Bu}$ nedenle araştırmanın, yönetim ve organizasyon alandaki bir boşluğu dolduracağı değerlendirilmektedir.

\section{Araştırmanın Modeli}

Araştırmada test edilecek model, ilişki yönüyle etraflı ve tanımlayıcı niteliktedir. Şekil 1'de ifade edilen modelde gösterilen ilişkiler çalışma sırasında incelenmeye çalışılacaktır. Modele göre, işgörenlerin işe adanmışlıkları ile örgütsel özdeşleşme arasında olumlu yönde bir ilişki söz konusudur. Ayrıca bu modele göre işgörenin performans algısı hem işgören adanmışlı̆̆ı ile hem de örgütsel özdeşleşme ile olumlu yönde bir ilişkiye sahiptir.

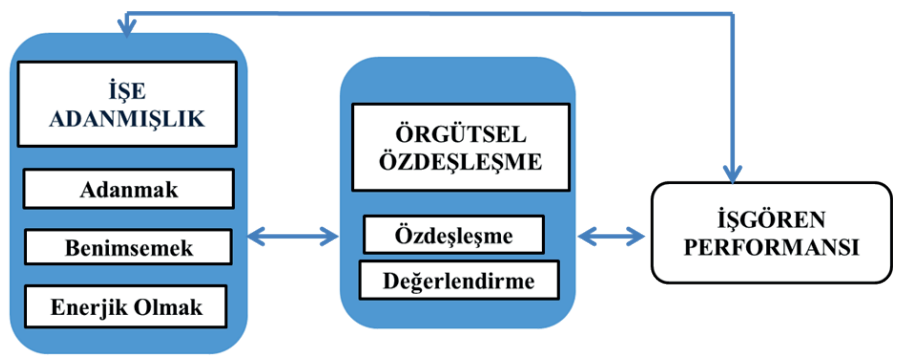

Şekil 1. İşgörenlerin İşe Adanmışlık Düzeyleri ve Örgütsel Özdeşleşme İlişkisinin Performans Algısına Etkilerine Yönelik Araştırmanın Modeli 


\section{Ana Kütle ve Örneklem}

Araştırmamızdaki hedef kitle kurum ve kuruluşlarda görev yapan memur, işçi, hizmetli, şoför, güvenlik görevlisi gibi her sınıftan işgörenlerdir. Araştırmanın başında amacımız büyük bir kurumda bu araştırmayı neticelendirmekti, ancak büyük kurumlardan gerekli müsaade alınamadığından dolayı, anketimizin kurumsal nitelik taşıyan iş yerlerinde uygulanmasına yönelik bir çalışmaya yönelinmiştir. Araştırma sürecinde 26 adet yazılı mektup, 13 adet elektronik mektup ve 13 adet yüz yüze görüşme olmak üzere toplam 52 kurum ve kuruluşa bizzat müracaat edilmiştir. Bu müracaatlardan yaklaşık yarısına yazılı veya sözlü olarak cevap verilmiş; ancak aşağıda belirtilen dört kurum veya kuruluştan "uygundur" cevabı alınabilmiştir.

Araştırmanın ana kütlesini yukarıda adı geçen kurum/kuruluş çalışanlarından toplam 6182 personel oluşturmaktadır. Araştırma yapıldığı dönemde Ankara Büyükşehir Belediyesi Fen İşleri Dairesinde yaklaşı 5.300 işgören, Eşkişehir Odunpazarı Belediyesi Merkez binasında yaklaşık 230 işgören, AFAD Başkanlığı Merkez binasında yaklaşık 450 işgören ve ASİS Elektronik ve Bilişim A.Ş.'de yaklaşık 200 işgören istihdam edildiği ifade edilmiş olup, bunlar kesin rakamlar değildir. Anket uygulaması için bu sayıya ulaşmamız hem zaman hem de maliyet açısından mümkün olmadığından gelişigüzel örneklem tercih edilmiştir. Bu kurum ve kuruluşlardan gönüllü olarak araştırmaya katılanların ortak özelliği çeşitli düzeylerde görev yapan işgören olmalarıdır. Elde edilen verilerin Tablo.1'de gösterilen $\alpha=0.05$ ve $\mathrm{q}=0,05$ orana göre bu araştırmada ana kütle-örneklem büyüklüğünün yeterli olduğu değerlendirilmektedir.

Tablo 1

$\alpha=0.05$ İçin Örneklem Büyüklükleri

\begin{tabular}{lccc}
\hline \multirow{2}{*}{ Evren Büyüklüğ̈̈ } & \multicolumn{3}{c}{$+\mathbf{0 . 0 5}$ örnekleme hatası (d) } \\
\cline { 2 - 4 } & $\mathbf{p = 0 . 5}$ ve $\mathbf{q}=\mathbf{0 . 5}$ & $\mathbf{p}=\mathbf{0 . 8}$ ve $\mathbf{~ q = 0 . 2}$ & $\mathbf{p = 0 . 3}$ ve $\mathbf{q}=\mathbf{0 . 7}$ \\
\hline 500 & 217 & 165 & 196 \\
750 & 254 & 185 & 226 \\
1000 & 278 & 198 & 244 \\
2500 & 333 & 224 & 286 \\
10000 & 370 & 240 & 313 \\
100000 & 383 & 245 & 322 \\
1000000 & 384 & 246 & 323 \\
100 milyon & 384 & 245 & 323 \\
\hline
\end{tabular}

Kaynak: Yazıcıŏlu ve Erdoğan (2004:50); Akt.Yirik, Ş. vd. (2016:10). 
Ankara Büyükşehir Belediyesinden 555 adet ve Eskişehir Odunpazarı Belediyesi çalışanlarından 92 adet, Ankara'da AFAD Başkanlığı Merkez Binasında çalışanlardan 98 adet ve İstanbul ilinde ise ASISS Elektronik ve Bilişim A.Ş. çalışanlarından 98 adet olmak üzere toplam 843 katılımcıyı kapsamaktadır.

\section{Analiz Yöntemi}

Yapılan araştırmanın analiz aşamasında ilk olarak katılımcıların demografik bilgilerine ilişkin tanımlayıcı istatistiki bilgiler verilmiştir. Daha sonra ölçeklere ilişkin geçerlilik ve güvenirlilik yapılmıştır. Geçerlilik analizi için, Açıklayıcı Faktör Analizi yapılmış, sonrasında kurulan yapının test edilmesi için Doğrulayıcı Faktör Analizi (DFA) AMOS yardımıyla analiz edilmiştir. Daha sonra ölçek güvenirliliği için hem ölçeğin hem de ölçeğin alt boyutlarının iç tutarlılığını tespit etmek için Cronbach-Alfa katsayısı incelenmiştir. Elde edilen bulgular $\% 95$ güven aralığında \%5 anlamlılık düzeyinde değerlendirilmiştir.

Analiz sürecinde verilerin normal dağılım gösterdiği durumlarda iki değişken karşılaştırmalarında bağımsız örneklem t-testi, ikiden fazla değişken karşılaştırmalarında ANOVA testi kullanılmıştır. Verilerin normal dağılım göstermediği durumlarda ise ikiden fazla değişken mevcut olduğu için non parametrik testlerden Kruskal Wallis testi kullanılmıştır. Bu test ile birlikte elde edilen sonuçlara göre ikişerli gruplamalar yapılarak Mann Whitney U testi yardımıyla gruplar arası farklılıklar belirlenmiştir. Hipotezlerin testi Korelasyon Analizi ve Yapısal Eşitlik Modeli (YEM) aracılığıyla yapılmıştır. Bütün araştırmanın analizinde SPSS 24.0, ve AMOS 24.0 istatistiki programları kullanılmıştır.

\section{Araştırmanın Varsayımları}

Araştırmaya yönelik varsayımlar aşağıda sıralanmıştır:

- Katılımcıların ana kütleyi temsil etme yeteneğine sahip olduğu,

- Katılımciların anket sorularını samimi olarak yanıtladığı,

- Araştırma sonuçlarına ulaşabilmek amacıyla en uygun istatistiki yöntemlerin seçildiği,

- Araştırmada kullanılan ölçme programlarının hâlihazırda geçerli ve güvenilir olduğu. 


\section{Araştırmanın Sınırlılıkları}

Araştırmaya yönelik sınırlamalar aşağıda sıralanmıştır:

- Araştırma, konu ve uygulama yönüyle sınırlandırılmış olup zaman, maliyet ve imkânlar bakımından belli kısıtlar taşımaktadır.

- Araştırmanın konu açısından kapsamını; işgörenlerin işe adanmışlık düzeyleri ve örgütsel özdeşleşme ilişkisinin performans algılarına etkilerini belirlemeye yönelik bir araştırma oluşturmaktadır.

- Uygulama açısından araştırma, Ankara ve Eskişehir illerinde belediye çalışanlarını, Ankara'da AFAD Başkanlığı Merkez Binasında çalışanları ve İstanbul ilinde ise ASİS Elektronik ve Bilişim A.Ş. çalışanlarını kapsamaktadır.

- Araştırma, sonuçlarının genellenmesi gibi bir amaç taşınmamaktadır.

- $\mathrm{Bu}$ araştırma sonucu itibariyle elde edilen verilerin araştırmacı tarafindan değerlendirmesini yansıtmakta olup, anket yapılmasına müsaade eden kurumların görüşlerini yansıtmamaktadır.

\section{Araştırmada Kullanılan Veri Toplama Yöntemi}

Araştırmada birinci elden veri toplama yöntemlerinden biri olan anket yöntemi kullanılmıştır. Araştırmanın anket formu 4 bölüm ve 46 sorudan oluşmaktadır. Birinci bölümde Demografik Bilgiler (7 soru), ikinci bölümde İşe Adanmışlık Ölçeği soruları (13 soru), üçüncü bölümde Örgütsel Özdeşleşme Ölçeği soruları (12 soru) ve dördüncü bölümde İşgören Performans Algısı ölçeği soruları (14 Soru) olmak üzere toplam 46 sorudan oluşmaktadır.

Birinci bölüm, araştırmaya katılan işgörenlerin demografik özelliklerinin belirlenmesine yönelik sorulardan oluşmaktadır. Sorular; "Cinsiyet, Yaş, Medeni Durum, Eğitim durumu, Kaç yıldır bu kurumda çalışıyorsunuz?, Statü ve Toplam iş tecrübesi?" sorularından oluşmaktadır.

İkinci bölümde, Schaufeli ve arkadaşları (2006) tarafından geliştirilerek (Utrecht Work Engagement Scale/Utrecht İşe Adanma Ölçeği) UWES-9'dan alınan 9 soru ve UWES-17'den alınan 4 soru olmak üzere, toplam 13 sorudan oluşan "İşe Adanma Anketi" Türkçeye çevrilerek kullanılmıştır (Shaufeli and Bakker, 2004: 4-11; Schaufeli et al., 2006: 706-707). 
Üçüncü bölümde Örgütsel Özdeşleşme Ölçeği olarak, iki araştırmacı grubu tarafindan geliştirilmiş iki farklı ölçekten oluşan bir kombinasyon Türkçeye çevrilerek kullanılmıştır. Bunlardan ilki Mael ve Ashforth (1992) tarafından geliştirilen 6 maddelik, ikinci kısmı Van Dick ve arkadaşları (2004) tarafından geliştirilen 6 maddelik olmak üzere toplam 12 maddelik özdeşleşme ölçeği bu araştırmada kullanılmıştır.

Dördüncü bölümde bu araştırmada işgörenlerin performans algısının ölçülmesinde kullanılan ölçek ise toplam 14 sorudan oluşan iki farklı araştırmadan alınan bir kombinasyon kullanılmıştır. Performans algısı anketini oluşturan ilk 4 anket sorusu, önce Kirkman ve Rosen (1999), daha sonra ise, Sigler ve Pearson (2000) tarafından araştırmalarda kullanılan Çöl (2008) tarafından ortaya çıkabilecek potansiyel hataları giderebilmek amacıyla her iki dile ve konuya hakim bir kişi tarafından ifadelerin İngilizceden Türkçeye çevirileri yapılarak kullanılmıştır. Performans algısı anketini oluşturan sonraki 3 soru (5-7) ise Fuentes ve arkadaşları (2004) ile Rahman ve Bullock (2004) tarafından geliştirilen Göktaş (2004) tarafından Türkçeye uyarlanan bir ölçekten alınmıştır. Son 7 soru (8-14) uzman görüşü doğrultusunda hazırlanmış olup, işgörenin performans algısını tespit amacıyla performans ölçeğine ilave edilmiştir.

Anketlerin uygulanma şekli; Ankara Büyükşehir Belediyesi, AFAD Başkanlığı ile Eskişehir Odunpazarı Belediyesinde (745 adedi) yüz yüze metodu ile İstanbul'daki ASİS A.Ş. çalışanlarına (98 adedi) posta yolu metodu ile olmuştur.

\section{Araștırmada Elde Edilen Verilerin Analizleri}

Tablo 2'de verilen Faktör analizi, araştırmaya konu olan ölçeğin ifadelerini açıklamak için kullanılan maddeleri gruplandırarak değişken sayısı azaltılmasını sağlamak yanında ifadelerin alt boyutlarını belirlemek amacıyla kullanılmaktadır. $\mathrm{Bu}$ analizin gücünü görebilmek için Kaiser-Meyer-Olkin (KMO) ve Bartlett Küresellik Testi sonuçlarına bakılmaktadır. KMO değeri 0 ila 1 arasında değer almaktadır. Bu değer 1'e yaklaştıkça faktörler daha güvenilir olduğu kabul edilmektedir. Genel olarak 0,700’ün üzerinde olan değerler faktörlerin açıklama gücünün iyi olduğunu ifade etmektedir. 
Tablo 2

Faktör Analizi Tablosu

\begin{tabular}{|c|c|c|c|c|c|c|c|c|}
\hline & \multicolumn{3}{|c|}{ İŞE ADANMIŞLIK } & \multicolumn{3}{|c|}{$\begin{array}{c}\text { ÖRGÜTSEL } \\
\text { ÖZDEŞLEŞME }\end{array}$} & \multicolumn{2}{|c|}{$\begin{array}{c}\text { İŞGÖREN } \\
\text { PERFORMANS } \\
\text { ALGISI }\end{array}$} \\
\hline & 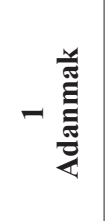 & 小 & 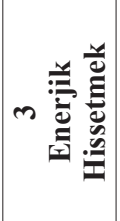 & & 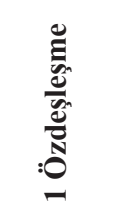 & 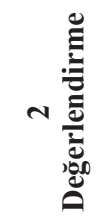 & & 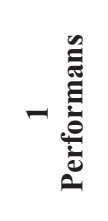 \\
\hline İ6 & ,790 & & & Ö6 & ,817 & & $\mathrm{P} 4$ & ,766 \\
\hline İ5 & ,780 & & & Ö5 & ,797 & & P3 & ,765 \\
\hline İ8 & ,774 & & & Ö7 & ,794 & & P8 & ,764 \\
\hline $\mathrm{I} 4$ & ,655 & & & Ö2 & ,739 & & P9 & ,742 \\
\hline $\mathrm{I} 2$ & ,651 & & & Ö4 & ,729 & & P11 & ,737 \\
\hline İ10 & & ,820 & & Ö12 & ,688 & & $\mathrm{P} 2$ & ,732 \\
\hline İ13 & & ,794 & & Ö3 & 672 & & P13 & ,726 \\
\hline İ11 & & ,746 & & Ö11 & ,633 & & P10 & ,719 \\
\hline İ1 & & &, 850 & Ö1 & ,557 & & P14 & ,707 \\
\hline \multirow[t]{5}{*}{ İ3 } & & & ,728 & Ö10 & &, 523 & P12 & ,694 \\
\hline & & & & Ö8 & & ,927 & P1 & ,677 \\
\hline & & & & & & & P7 & ,664 \\
\hline & & & & & & & P6 & ,646 \\
\hline & & & & & & & $\mathrm{P} 5$ & ,644 \\
\hline $\begin{array}{l}\text { Faktör } \\
\text { Yükleri }\end{array}$ & 32,069 & 25,202 & 21,991 & & 44,427 & 22,616 & & 51,030 \\
\hline KMO & \multicolumn{3}{|c|}{,941 } & \multicolumn{3}{|c|}{927} & \multicolumn{2}{|c|}{,931 } \\
\hline $\begin{array}{l}\text { Bartlett } \\
\text { Testi }\end{array}$ & \multicolumn{3}{|c|}{6340,777} & \multicolumn{3}{|c|}{4271,340} & \multicolumn{2}{|c|}{6997,009} \\
\hline Sd. & \multicolumn{3}{|c|}{45} & \multicolumn{3}{|c|}{55} & \multicolumn{2}{|c|}{91} \\
\hline Sig. & \multicolumn{3}{|c|}{, 000} & \multicolumn{3}{|c|}{, 000} & \multicolumn{2}{|c|}{, 000} \\
\hline $\begin{array}{l}\text { Açıklanan } \\
\text { Toplam } \\
\text { Varyans } \\
\text { Yükü }\end{array}$ & \multicolumn{3}{|c|}{79,262} & \multicolumn{3}{|c|}{67,043} & \multicolumn{2}{|c|}{51,030} \\
\hline
\end{tabular}

Yapılan açıklayıcı faktör analizi sonuçlarına göre, “İşe Adanmışlık” ölçeğinin KMO değeri 0,941, Bartlett testi değeri ise anlamlı çıkmıştır $\left(X^{2}=6340,777\right.$; $\mathrm{p}<0,001)$. "Örgütsel Özdeşleşme” ölçeğinin KMO değeri 0,927, Bartlett testi değeri ise anlamlı çıkmıştır $\left(X^{2}=4271,340 ; p<0,001\right)$. Araştırmada kullanılan diğer ölçek olan "İşgören Performansı" ölçeğinin KMO değeri 0,931, Bartlett testi değeri ise anlamlı çıkmıştır $\left(X^{2}=6997,009 ; p<0,001\right)$. Bu sonuçlara göre, bütün ölçeklerin KMO ve Barlett Küresellik Testi sonuçlarının anlamlı çıkması, bunların yükssek derece güvenilir ölçek olduklarını göstermektedir. 


\section{Doğrulayıcı Faktör Analizi}

Açıklayıcı Faktör Analizi ile belirlenen alt boyutların yapılarının test edilebilmesi için Doğrulayıcı Faktör Analizi (DFA) AMOS 24.0 yardımıyla çözümlenmiştir. Doğrulayıcı Faktör Analizi önceden belirlenmiş olan bir yapının model olarak doğrulanıp doğrulanmadığını belirlenmesi amacıyla kullanılmaktadır.

Önceden yapılan Açıklayıcı Faktör Analizi sonucunda analiz dışında bırakılan maddeler Doğrulayıcı Faktör Analizi sonucunda da düşük yük değerlerine sahip oldukları için analiz dışında bırakılmıştır. Doğrulayıcı Faktör Analizi sonucunda elde edilen uyum değerleri ve kabul edilebilen uyum aralıkları Tablo 3 'te verilmiştir.

Tablo 3

Doğrulayıcı Faktör Analizi İçin Uyum İndeksleri

\begin{tabular}{llccc}
\hline \multicolumn{1}{c}{ Indeks } & Kabul Edilebilir Uyum & İşe Adanmışlık & $\begin{array}{c}\text { Örgütsel } \\
\text { Özdeşleşme }\end{array}$ & $\begin{array}{c}\text { İşgören } \\
\text { Performansı }\end{array}$ \\
\hline CMIN/DF & $3 \leq \chi^{2} \leq * 5$ & 5,411 & 4,829 & 6,956 \\
CFI & $0,90 \leq \mathrm{CFI} \leq 0,97^{*}$ &, 978 &, 965 &, 947 \\
NFI & $0,90 \leq \mathrm{NFI} \leq 0,95^{*}$ &, 974 &, 956 &, 939 \\
GFI & $0,85 \leq \mathrm{GFI} \leq 0,90^{*}$ &, 864 &, 862 &, 928 \\
SRMR & $0,05 \leq \mathrm{SRMR} \leq 0,08^{*}$ &, 074 &, 051 &, 059 \\
RMSEA & $0,05 \leq \mathrm{RMSEA} \leq 0,08^{*}$ &, 072 &, 067 &, 074 \\
\hline
\end{tabular}

* Schermelleh-Engel et al. (2003:43); Mueller, (1996: 84).

Analizde bağlantılı görülen maddeler için modifikasyona gidilmiştir. $\mathrm{Bu}$ sayede değerler iyileştirilmiştir. Tablo 3'te görüldüğü gibi bütün değerlerin kabul edilebilir bir değerde olduğu belirlenmiştir (Schermelleh-Engel and Moosbrugger, 2003:42; Mueller, 1996: 84).

\section{Araştırmanın Hipotezleri}

Araştırmamız doğrultusunda hazırlanan hipotezler işgörenlerin işe adanmışlık tutumları ile örgütsel özdeşleşme tutumları arasındaki ilişkileri, işgörenlerin işe adanmışl1k tutumları ile performans algısına yönelik ilişkileri ve işgörenlerin örgütsel özdeşleşme tutumları ile performans algısına yönelik ilişkileri, değişkenlerin alt boyutları bazında açıklamaya yönelik geliştirilmiştir. Ayrıca örgütsel özdeşleşme ve alt boyutlarının, işe adanmışlık ve alt boyutları ile performans algısına yönelik aracı değişken rolüne yönelik hipotezlerde aşağıda sunulmuştur. 


\section{Hipotez 1}

$\mathrm{H}_{0 \text { : }}$ İşe adanma ile örgütsel özdeşleşme arasında bir ilişki yoktur.

$\mathrm{H}_{1:}$ İşe adanma ile örgütsel özdeşleşme arasında bir ilişki vardır.

\section{Hipotez 2}

$\mathrm{H}_{0 \text { : }}$ Işe adanma ile değerlendirme arasında bir ilişki yoktur.

$\mathrm{H}_{1:}$ İşe adanma ile değerlendirme arasında bir ilişki vardır.

\section{Hipotez 3}

$\mathrm{H}_{0:}$ İşe adanma ile işgören performans algısı arasında bir ilişki yoktur.

$\mathrm{H}_{1:}$ İşe adanma ile işgören performans algısı arasında bir ilişki vardır.

\section{Hipotez 4}

$\mathrm{H}_{0}$ : İşte enerjik olmak ile örgütsel özdeşleşme arasında bir ilişki yoktur.

$\mathrm{H}_{1}$ : İşte enerjik olmak ile örgütsel özdeşleşme arasında bir ilişki vardır.

\section{Hipotez 5}

$\mathrm{H}_{0}$ : İşte enerjik olmak ile değerlendirme arasında bir ilişki yoktur.

$\mathrm{H}_{1}$ : İşte enerjik olmak ile değerlendirme arasında bir ilişki vardır.

\section{Hipotez 6}

$\mathrm{H}_{0}$ : İşte enerjik olmak ile işgören performans algısı arasında bir ilişki yoktur.

$\mathrm{H}_{1}$ : İşte enerjik olmak ile işgören performans algısı arasında bir ilişki vardır.

\section{Hipotez 7}

$\mathrm{H}_{0}$ : İşi benimsemek ile örgütsel özdeşleşme arasında bir ilişki yoktur.

$\mathrm{H}_{1}$ : İşi benimsemek ile örgütsel özdeşleşme arasında bir ilişki vardır.

\section{Hipotez 8}

$\mathrm{H}_{0}$ : İşi benimsemek ile değerlendirme arasında bir ilişki yoktur.

$\mathrm{H}_{1}$ : İşi benimsemek ile değerlendirme arasında bir ilişki vardır.

\section{Hipotez 9}

$\mathrm{H}_{0}$ : İşi benimsemek ile işgören performans algısı arasında bir ilişki yoktur.

$\mathrm{H}_{1}$ : İşi benimsemek ile işgören performans algısı arasında bir ilişki vardır. 


\section{Hipotez 10}

$\mathrm{H}_{0}$ : Örgütsel özdeşleşme ile işgören performans algısı arasında bir ilişki yoktur. $\mathrm{H}_{1}$ : Örgütsel özdeşleşme ile işgören performans algısı arasında bir ilişki vardır.

\section{Hipotez 11}

$\mathrm{H}_{0}$ : Değerlendirme ile işgören performans algısı arasında bir ilişki yoktur.

$\mathrm{H}_{1}$ : Değerlendirme ile işgören performans algısı arasında bir ilişki vardır.

\section{Hipotez 12}

$\mathrm{H}_{0}$ : Örgütsel özdeşleşmenin, işe adanma ile işgören performans algısı arasında aracı değişken rolü yoktur.

$\mathrm{H}_{1}$ : Örgütsel özdeşleşmenin, işe adanma ile işgören performans algısı arasında aracı değişken rolü vardır.

\section{Hipotez 13}

$\mathrm{H}_{0}$ : İşi değerlendirmenin, işe adanma ile işgören performans algısı arasında aracı değişken rolü yoktur.

$\mathrm{H}_{1}$ : İşi değerlendirmenin, işe adanma ile işgören performans algısı arasında aracı değişken rolü vardır.

\section{Hipotez 14}

$\mathrm{H}_{0}$ : Örgütsel özdeşleşmenin, işte enerjik olmak ile işgören performans algısı arasında aracı değişken rolü yoktur.

$\mathrm{H}_{1}$ : Örgütsel özdeşleşmenin, işte enerjik olmak ile işgören performans algısı arasında aracı değişken rolü vardır.

\section{Hipotez 15}

$\mathrm{H}_{0}$ : İşi değerlendirmenin, işte enerjik olmak ile işgören performans algısı arasında aracı değişken rolü yoktur.

$\mathrm{H}_{1}$ : İşi değerlendirmenin, işte enerjik olmak ile işgören performans algısı arasında aracı değişken rolü vardır.

\section{Hipotez 16}

$\mathrm{H}_{0}$ : Örgütsel özdeşleşmenin, işi benimsemek ile işgören performans algısı arasında aracı değişken rolü yoktur. 
$\mathrm{H}_{1}$ : Örgütsel özdeşleşmenin, işi benimsemek ile işgören performans algısı arasında aracı değişken rolü vardır.

\section{Hipotez 17}

$\mathrm{H}_{0}$ : İşi değerlendirmenin, işi benimsemek ile işgören performans algısı arasında aracı değişken rolü yoktur.

$\mathrm{H}_{1:}$ İşi değerlendirmenin, işi benimsemek ile işgören performans algısı arasında aracı değişken rolü vardır.

\section{Araştırmada Anketinin Oluşturulması ve Faktör Analizi}

Birinci değişken olarak ele alınan İşe Adanmışlık Ölçeği için, 3 madde birden fazla boyutta yüksek faktör yükü olması sebebiyle analiz dışı bırakılmıştır. Ölçeğin alt faktörleri orijinal ölçekte olduğu gibi 3'e ayrıldığı, bu faktörler sırasıyla "Adanmak, Benimsemek ve Enerjik Olmak" olarak belirlenmiştir. UWES ölçeğinin orijinalindeki şekliyle bu çalışmada 7'li Likert uygulanmıştır [Çok Seyrek (Yılda bir kaç defa veya daha az): 1, Seyrek (Ayda bir veya daha az):2, Bazen (Ayda bir kaç defa): 3, Fikrim Yok:4, Siklıkla (Haftada bir defa): 5, Çok Sik (Haftada bir kaç defa): 6, Her Zaman (Her gün): 7].

Örgütsel Özdeşleşme Ölçeği olarak, iki araştırmacı grubu tarafından geliştirilmiş iki farklı ölçekten, toplam 12 sorudan oluşan bir kombinasyon Türkçeye çevrilerek kullanılmaktadır. Bunlardan ilki Mael ve Ashforth (1992) tarafından geliştirilen 6 maddelik bir ölçektir. Örgütsel Özdeşleşme Ölçeğinin diğer bölümünde, Van Dick ve arkadaşları (2004) tarafindan geliştirilen 6 soruluk (2, 4, 6, 8,10 ve 12. sorular) ölçeği bu araştırmada kullanılmıştır. İkinci değişken olarak ele alınan ve açıklayıcı faktör analizi Örgütsel Özdeşleşme Ölçeği, yapılan analiz sonucunda madde korelasyon değeri .25'den küçük olan ve birden fazla boyutta yüksek faktör yükü olan, ayrıca yükler arasındaki farkın .10'dan düşük olan maddeleri analiz dışında bırakılmıştır. Bu kapsamda bir madde analizden çıkarılmıştır. Geriye kalan 11 madde ile analiz tekrar edilmiştir. Orijinal ölçekte 5 alt faktör olmasına rağmen, yapılan açıklayıcı faktör analizinde sonucunda ölçek iki alt faktöre ayrılmıştır. Bunlar, ilk faktör olarak "Özdeşleşme" boyutu ve ikinci faktör olarak "Değerlendirme" boyutu belirlenmiştir. Bu araştırmada "Özdeşleşme" ve "Değerlendirme" boyutu olarak iki boyutta ölçüm yapılmıştır. Bu araştırmanın öz değerinin (eigenvalue) değişkenlerin \%74'ünü açıkladığı tespit edilmiş ve ölçeğin güvenilirliğinin iyi düzeyde olduğu belirtilmiştir. (Dick et al. 2004:175-176). Bu çalışmada 5'li Likert uygulanmıştır 
(Kesinlikle Yansitmamakta, Yansitmamakta, Fikrim Yok, Yansitmakta ve Kesinlikle Yansitmakta).

İşgörenlerin performans algısının ölçülmesinde ise iki farklı araştırmadan alınan toplam 14 sorudan oluşan bir ölçek kullanılmıştır. Performans algısı anketini oluşturan ilk 4 anket sorusu, önce Kirkman ve Rosen (1999), daha sonra ise, Sigler ve Pearson (2000) tarafından araştırmalarda kullanılan Çöl (2008) tarafından ortaya çıkabilecek potansiyel hataları giderebilmek amacıyla her iki dile ve konuya hakim bir kişi tarafından ifadelerin İngilizceden Türkçeye çevirileri yapılarak kullanılmıştır. Performans algısı anketini oluşturan sonraki 3 soru (5-7) ise Fuentes vd. (2004) ile Rahman ve Bullock (2004) tarafindan geliştirilen Göktaş (2004) tarafindan Türkçeye uyarlanan ölçeğin üç maddesi geçerlik ve güvenirlik çalışmaları yapıldıktan sonra (Cronbach alfa güvenirlik katsayısı 0.91) kullanılmıştır (Göktaş, 2004: 90-93; Şehitoğlu ve Zehir, 2010; 106-120). Son 7 soru (8-14) uzman görüşü doğrultusunda hazırlanmış olup, işgörenin performans algısını tespit amacıyla performans ölçeğine ilave edilmiştir. Yapılan incelemede ulusal yazında çoğu araştırmacılar tarafından 5'li Likert uygulandığı tespit edildiğinden, bu çalışmada da 5'li Likert uygulanmıştır (Seçenekler: Kesinlikle Katılıyorum, Katılıyorum, Kararsızım, Katılmıyorum ve Kesinlikle Katılmıorum).

Tablo 4'te verilen Faktör analizi, araştırmaya konu olan ölçeğin ifadelerini açıklamak için kullanılan maddeleri gruplandırarak değişken sayısı azaltılmasını sağlamak yanında ifadelerin alt boyutlarını belirlemek amacıyla kullanılmaktadır. $\mathrm{Bu}$ analizin gücünü görebilmek için Kaiser-Meyer-Olkin (KMO) ve Bartlett Küresellik Testi sonuçlarına bakılmaktadır. KMO değeri 0 ila 1 arasında değer almaktadır. Bu değer 1'e yaklaştıkça faktörler daha güvenilir olduğu kabul edilmektedir. Genel olarak 0,70'in üzerinde olan değerler faktörlerin açıklama gücünün iyi olduğunu ifade etmektedir.

Yapılan açıklayıcı faktör analizi sonuçlarına göre, "Işse Adanmışlık” ölçeğinin KMO değeri 0,941, Bartlett testi değeri ise anlamlı çıkmıştır $\left(\mathrm{X}^{2}=6340,777\right.$; $\mathrm{p}<0,001)$. "Örgütsel Özdeşleşme” ölçeğinin KMO değeri 0,927, Bartlett testi değeri ise anlamlı çıkmıştır $\left(X^{2}=4271,340 ; p<0,001\right)$. Araştırmada kullanılan diğer ölçek olan "İş̧gören Performansı" ölçeğinin KMO değeri 0,931, Bartlett testi değeri ise anlamlı çıkmıştır $\left(\mathrm{X}^{2}=6997,009 ; \mathrm{p}<0,001\right)$. Bu sonuçlara göre, bütün ölçeklerin KMO ve Barlett Küresellik Testi sonuçlarının anlamlı çıkması, bunların yüksek derece güvenilir ölçek olduklarını göstermektedir. 
Tablo 4

Faktör Analizi Tablosu

\begin{tabular}{|c|c|c|c|c|c|c|c|c|}
\hline & \multicolumn{3}{|c|}{ Işe adanmışlık } & \multicolumn{3}{|c|}{ Örgütsel özdeşleşme } & \multicolumn{2}{|c|}{$\begin{array}{c}\text { Performans } \\
\text { algisı }\end{array}$} \\
\hline & \multirow[t]{2}{*}{ 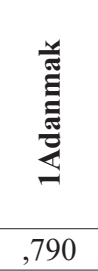 } & \multirow[t]{2}{*}{ 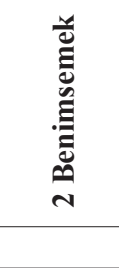 } & 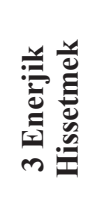 & \multicolumn{2}{|r|}{ 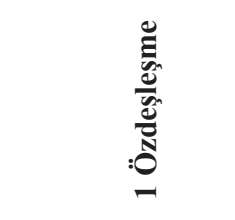 } & \multirow[t]{2}{*}{ ৩ } & & 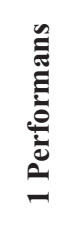 \\
\hline İ6 & & & & Ö6 & ,817 & & $\mathrm{P} 4$ & ,766 \\
\hline İ5 & ,780 & & & Ö5 & ,797 & & P3 & ,765 \\
\hline İ8 &, 774 & & & Ö7 & ,794 & & P8 & ,764 \\
\hline İ4 & ,655 & & & Ö2 & ,739 & & P9 & ,742 \\
\hline İ2 & ,651 & & & Ö4 &, 729 & & P11 & ,737 \\
\hline İ10 & & ,820 & & Ö12 & ,688 & & $\mathrm{P} 2$ & ,732 \\
\hline İ13 & & ,794 & & Ö3 & ,672 & & P13 & ,726 \\
\hline İ11 & & ,746 & & Ö11 & ,633 & & P10 & ,719 \\
\hline İ1 & & &, 850 & Ö1 &, 557 & & P14 &, 707 \\
\hline \multirow[t]{5}{*}{ İ3 } & & & ,728 & Ö10 & & ,523 & P12 & ,694 \\
\hline & & & & Ö8 & & ,927 & $\mathrm{P} 1$ & 677 \\
\hline & & & & & & & $\mathrm{P} 7$ & ,664 \\
\hline & & & & & & & P6 & ,646 \\
\hline & & & & & & & P5 & ,644 \\
\hline \begin{tabular}{|l|} 
Faktör \\
Yükleri
\end{tabular} & 32,069 & 25,202 & 21,991 & & 44,427 & 22,616 & & 51,030 \\
\hline KMO & ,941 & & & & ,92 & & & 31 \\
\hline \begin{tabular}{|l|} 
Bartlett \\
Testi
\end{tabular} & \multicolumn{3}{|c|}{6340,777} & \multicolumn{3}{|c|}{4271,340} & \multicolumn{2}{|c|}{6997,009} \\
\hline Sd. & \multicolumn{3}{|c|}{45} & \multicolumn{3}{|c|}{55} & \multicolumn{2}{|c|}{91} \\
\hline Sig. & \multicolumn{3}{|c|}{, 000} & \multicolumn{3}{|c|}{, 000} & \multicolumn{2}{|c|}{, 000} \\
\hline \begin{tabular}{|l|} 
Toplam \\
Varyans \\
Yükü \\
\end{tabular} & \multicolumn{3}{|c|}{79,262} & \multicolumn{3}{|c|}{67,043} & \multicolumn{2}{|c|}{51,030} \\
\hline
\end{tabular}

\section{Güvenirlilik}

Ölçeklerin güvenirlik katsayıları ve ölçekle ilgili tanımlayıcı istatistikler Tablo 5’te verilmiştir. İlk değişken olan “İşe Adanmışlık Ölçeğì”nin alt boyutlarından "adanma" boyutunun güvenirlik katsayısı 0,925, "Benimsemek” alt boyutunun güvenirlik katsayıs1 0,839 ve son alt boyut olan "enerjik olmak" boyutunun güvenirliği ise 0,840 şeklindedir. Toplam İşe Adanmışlık Ölçeği güvenirlilik katsayısı ise 0,940 şeklindedir. İkinci değişken olan “örgütsel özdeşleşme”nin alt boyutlarından “özdeşleşme”nin güvenirlik katsayısı 0,888 iken, “örgütsel özdeşleşme"nin diğer alt boyutu olan "değerlendirme" boyutunun güvenirlik katsayısı 0,698 şeklindedir. “Toplam Örgüsel Özdeşleşme Ölçeği” güvenirliliğine 
bakıldığında 0,894 şekilde olduğu belirlenmiştir. İşgören Performansı Ölçeği'nin güvenirliği 0,924 şeklindedir. Bu sonuçlar tüm ölçeklerin 0,700'e yakın ve 0,700'den büyük değerler aldığ 1 için oldukça güvenilir oldukları söylenebilir.

Tablo 5

Ölçeklere İlişkin İç Tutarlılık Katsayıları ve Tanımlayıcı Ístatistikleri

\begin{tabular}{lcc}
\hline \multicolumn{1}{c}{ Alt Boyutlar } & Madde Sayısı & Cronbach's Alpha \\
\hline Adanmak & 5 &, 925 \\
Benimsemek & 3 &, 839 \\
Enerjik Olmak & 2 &, 840 \\
Toplam İşe Adanmışlık & 10 &, 940 \\
Özdeşleşme & 9 &, 888 \\
Değerlendirme & 2 &, 698 \\
Toplam Örgütsel Özdeşleşme & 11 &, 894 \\
İşgören Performansı & 14 &, 924 \\
\hline
\end{tabular}

* Tüm değerler $\mathrm{p}<0,001$ düzeyinde anlamlıdır.

\section{Doğrulayıcı Faktör Analizi}

Açıklayıcı Faktör Analizi ile belirlenen alt boyutların yapılarının test edilebilmesi için Doğrulayıcı Faktör Analizi (DFA) AMOS 24.0 yardımıyla çözümlenmiştir. Doğrulayıcı Faktör Analizi önceden belirlenmiş olan bir yapının model olarak doğrulanıp doğrulanmadığını belirlenmesi amacıyla kullanılır.

Önceden yapılan Açıklayıcı Faktör Analizi sonucunda analiz dışında bırakılan maddelerin Doğrulayıcı Faktör Analizi sonucunda düşük yük değerlerine sahip oldukları için analiz dışında bırakılmıştır. Doğrulayıcı Faktör Analizi sonucunda elde edilen uyum değerleri ve kabul edilebilen uyum aralıkları Tablo 6'da verilmiştir.

Tablo 6

Doğrulayıcı Faktör Analizi İçin Uyum İndeksleri

\begin{tabular}{|llccc|}
\hline \multicolumn{1}{|c}{ Indeks } & Kabul Edilebilir Uyum & İşe Adanmışlık & $\begin{array}{c}\text { Örgütsel } \\
\text { Özdeşleşme }\end{array}$ & $\begin{array}{c}\text { İşgören } \\
\text { Performansı }\end{array}$ \\
\hline CMIN/DF & $3 \leq \chi^{2} \leq * 5$ & 5,411 & 4,829 & 6,956 \\
CFI & $0,90 \leq \mathrm{CFI} \leq 0,97^{*}$ &, 978 &, 965 &, 947 \\
NFI & $0,90 \leq \mathrm{NFI} \leq 0,95^{*}$ &, 974 &, 956 &, 939 \\
GFI & $0,85 \leq \mathrm{GFI} \leq 0,90^{*}$ &, 864 &, 862 &, 928 \\
SRMR & $0,05 \leq \mathrm{SRMR} \leq 0,08^{*}$ &, 074 &, 051 &, 059 \\
RMSEA & $0,05 \leq \mathrm{RMSEA} \leq 0,08^{*}$ &, 072 &, 067 &, 074 \\
\hline
\end{tabular}

* Schermelleh-Engel et al. (2003:43); Mueller, (1996: 84). 
Analizde bağlantılı görülen maddeler için modifikasyona gidilmiştir. $\mathrm{Bu}$ sayede değerler iyileştirilmiştir. Tablo 6'da görüldüğü gibi bütün değerlerin kabul edilebilir bir değerde olduğu belirlenmiştir (Schermelleh-Engel and Moosbrugger, 2003:42; Mueller, 1996: 84).

Faktör yapılarını tespit edebilmek için yapılan Doğrulayıcı Faktör Analizi sonucu aşağıda Şekil 2'de verilmiştir. Araştırmada kullanılan "İşe Adanmışlık" ölçeği için düşük faktör yüküne sahip 3 madde analiz dışında bırakılmıştır. Alt boyutlarından "Adanmak" ile "Benimsenmek" boyutları arasında yüksek korelasyon ilişkisi olduğu belirlenmiştir $(r=, 80 ; p<0,01)$. "Adanmak" boyutu ile "İşe Adanmışlık” boyutunun diğer alt boyutu olan "Enerjik Olmak" boyutu arasında yine pozitif yönlü yüksek korelasyon ilişkisi olduğu belirlenmiştir $(\mathrm{r}=, 89 ; \mathrm{p}<0,01)$. "Benimsemek" alt boyutu ile "Enerjik Olmak" alt boyutu arasında da pozitif yüksek korelasyon ilişkisi bulunmaktadır $(r=, 75 ; p<0,01)$. Ayrıca, i4 ile i8 maddeleri arasında negatif yönlü yüksek korelasyon ilişkisi nedeniyle modifikasyona gidilmiştir.

Araştırmada kullanılan bir diğer ölçek olan “Örgütsel Özdeşleşme” ölçeği için düşük faktör yüküne sahip bir madde analiz dışında bırakılmıştır. Alt boyutlarından "Özdeşleşme" ile "Değerlendirme" boyutları arasında pozitif yönlü yüksek korelasyon ilişkisi olduğu belirlenmiştir $(r=, 75 ; p<0,01)$. Ayrıca Ö1-Ö2; Ö2-Ö3; Ö6-Ö7 ve Ö11-Ö12 arasında yüksek korelasyon ilişkisi nedeniyle modifikasyona gidilmiştir.

Araştırmada kullanılan son ölçek olan "Performans" ölçeği için, P1-P2; P3P4; P5-P6; P8-P9 ve P11-P12 maddeleri arasında da yüksek korelasyon ilişkisi nedeniyle modifikasyonda bulunulmuştur. Bu sonuçlar itibari ile ölçeğin Açıklayıcı Faktör Analizi sonucu ile Doğrulayıcı Faktör Analizi sonuçları karşılaştırıldığında benzer sonuçlar elde edilmiştir. 


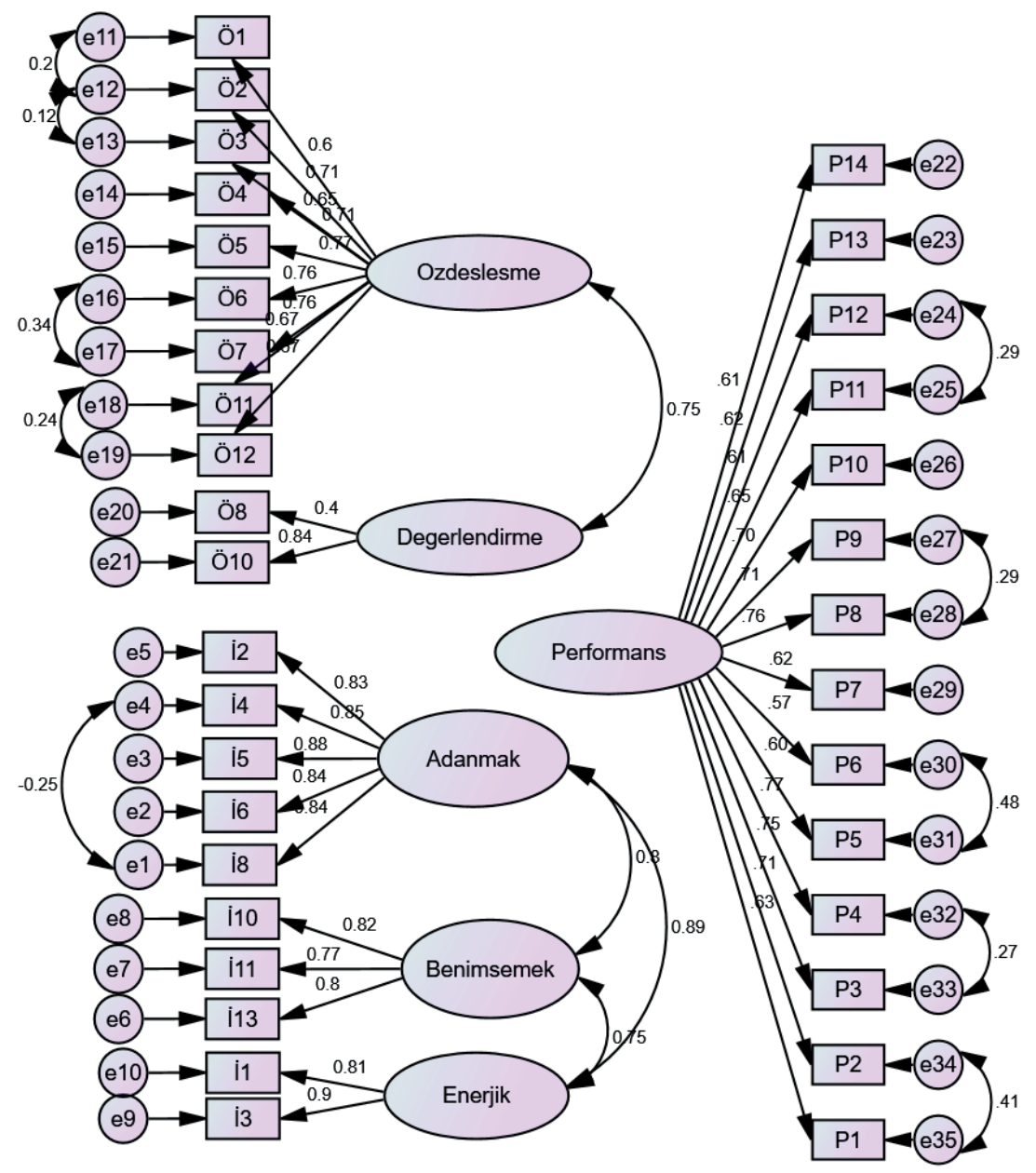

Şekil 2. Doğrulayıcı Faktör Analizi Yapısı

\section{Tanımlayıcı İstatistikler}

Araştırma anketlerini kriterlere uygun biçimde cevaplayan sayısı 843'tür. Araştırmaya katılanların 253'ünün Kadın (\%30), 590'ının Erkek (\%70) çalışanlardan oluştuğu belirlenmiştir. Araştırmaya katılanların 283'ünün Bekâr $(\% 33,6), 560$ 'ının Evli $(\% 66,4)$ bireylerden oluştuğu belirlenmiştir. Araştırmaya katılanların 123'ünün 18-25 yaş aralığında (\% 14,6), 330'unun 26-35 yaş aralığında $(\% 39,1), 241$ 'inin 36-45 yaş aralığında $(\% 28,6), 112$ 'sinin 46-55 
yaş aralığında $(\% 13,3)$ ve 37 'sinin ise 55 ve üzeri yaş aralığında $(\% 4,4)$ olduğu belirlenmiştir. Araştırmaya katılanların 140'ının İlköğretim (\%16,6), 262'sinin Lise (\%31,1), 376'sının Üniversite $(\% 44,6)$ ve 65'inin ise Lisansüstü $(\% 7,7)$ eğitim mezunu olduğu belirlenmiştir. Araştırmaya katılanların 14'ünün Yönetici $(\% 1,7), 60$ ’’nın Şef $(\% 7,1), 348$ 'inin İşçi $(\% 41,3)$, 139'unun Memur (\%16,5), 22 'sinin Mühendis (\%2,6), 32'sinin Tekniker $(\% 3,8), 12$ 'sinin Teknisyen (\%1,4), 26'sının Uzman $(\% 3,1)$ ve 190'ının diğer $(\% 22,5)$ mesleki unvanlara sahip belirlenmiştir. Araştırmaya katılanların 475'i 0-5 yıl arası (\%56,3), 224'ü 6-10 y1l arası (\%26,6), 73'ü 11-15 yıl arası (\%8,7), 55'i 16-25 y1l arası (\%6,5) ve 16 's1 26 ve üzeri süredir $(\% 1,9)$ aynı kurumlarında çalıştıkları belirlenmiştir. Araştırmaya katılanların 285'inin 0-5 y1l arası (\%33,8), 199'unun 6-10 y1l arası (\%23,6), 143'ünün 11-15 yıl arası (\%17,0), 151'inin 16-25 yıl arası (\%17,9), 56 'sının 26-35 yıl arası $(\% 6,6)$ ve 9'unun 36 yıl ve üzeri süredir $(\% 1,1)$ bir iş yerinde çalıştıkları belirlenmiştir.

\section{Yapısal Eşitlik Modeli (YEM) ile Hipotezlerin Test Edilmesi}

Araştırmada hipotezlerin test edilmesi için Yapısal Eşitlik Modellemesi (YEM) AMOS yardımıyla değişkenler arasındaki ilişkiler ve bu ilişkilerin değişkenlere etki edecek kadar güçlü olup olmadığı analiz edilmiştir. Tablo 8 'te YEM modeli uyum değerleri verilmiştir.

Tablo 8

YEM Uyum Değerleri

\begin{tabular}{lcc}
\hline İndeks & Kabul Edilebilir Uyum & Bulunan değer \\
\hline CMIN/DF & $3 \leq \chi^{2} \leq 5^{*}$ & 4,736 \\
CFI & $0,90 \leq \mathrm{CFI} \leq 0,97^{*}$ &, 902 \\
NFI & $0,90 \leq \mathrm{NFI} \leq 0,95^{*}$ &, 820 \\
GFI & $0,85 \leq \mathrm{GFI} \leq 0,90^{*}$ &, 857 \\
SRMR & $0,05 \leq \mathrm{SRMR} \leq 0,08^{*}$ &, 059 \\
RMSEA & $0,08 \leq \mathrm{RMSEA} \leq 0,05^{*}$ &, 079 \\
\hline
\end{tabular}

* Schermelleh-Engel et al. (2003:43); Mueller, (1996: 84).

Yapılan Yapısal Eşitlik Modeli Analizi (YEM) sonucunda elde edilen uyum indeksleri kabul edilebilir uyum değerleri içerisinde yer alması nedeniyle uygulanan modelin uygun bir model olduğu söylenebilir. Değerlerden CFI değeri $\mathrm{X}^{2}$ değerinin serbestlik derecesine bölünmesiyle elde edilir. CFI değeri $\mathrm{X}^{2} /$ $\mathrm{DF}=2328,436 / 536=4,736$ sonucu ile elde edilmiştir. Diğer değerlerden RMSEA değerinin kabul edilebilir değer olan 0,05 ile 0,08 arasında olması gerekmektedir. Sonuçlara bakıldığında bu değerin de 0,079 değeri ile belirlenen üst sınır ile alt 
sınır arasında olduğu görülmektedir. Varyans ve kovaryansın miktarının göstergesi olan GFI değeri, 0,85 ile 0,90 arasında değerler alır. GFI değerinin 0,857 olmas 1 ile 1'e yakınlığı sayesinde modelin iyi olduğu bu değerle de anlaşılmaktır (Schermelleh-Engel and Moosbrugger, 2003:42; Mueller, 1996: 84).

Şekil 3'te modele uygun Yapısal Eşitlik Modeli verilmiştir. Modelde hipotezlere uygun olarak verilen direk etkiler yanında direk etki olmayan moderatör ilişkilerde sorgulanmıştır. Araştırmada katılımcıların "İşe Adanmışlık" algıları ile "Örgütsel Özdeşleşme" algıları arasındaki ilişkinin yanı sıra "İşe Adanmışlık" algıları ile "İşgören Performans" algıları arasındaki ilişkide araştırılmıştır. Ayrıca, "Örgütsel Özdeşleşme” düzeyi ile "İşgören Performans Algısı" arasındaki ilişkiyle birlikte katılımcıların "İşe Adanmışlık" düzeyleri ile "İşgören Performans Algısı" arasındaki ilişkinin "Örgütsel Özdeşleşme" düzeylerinin ne derece etki ettiği "Örgütsel Özdeşleşme” alt boyutlarının aracı değişken olarak kullanılmasıyla araştırılmıştır.

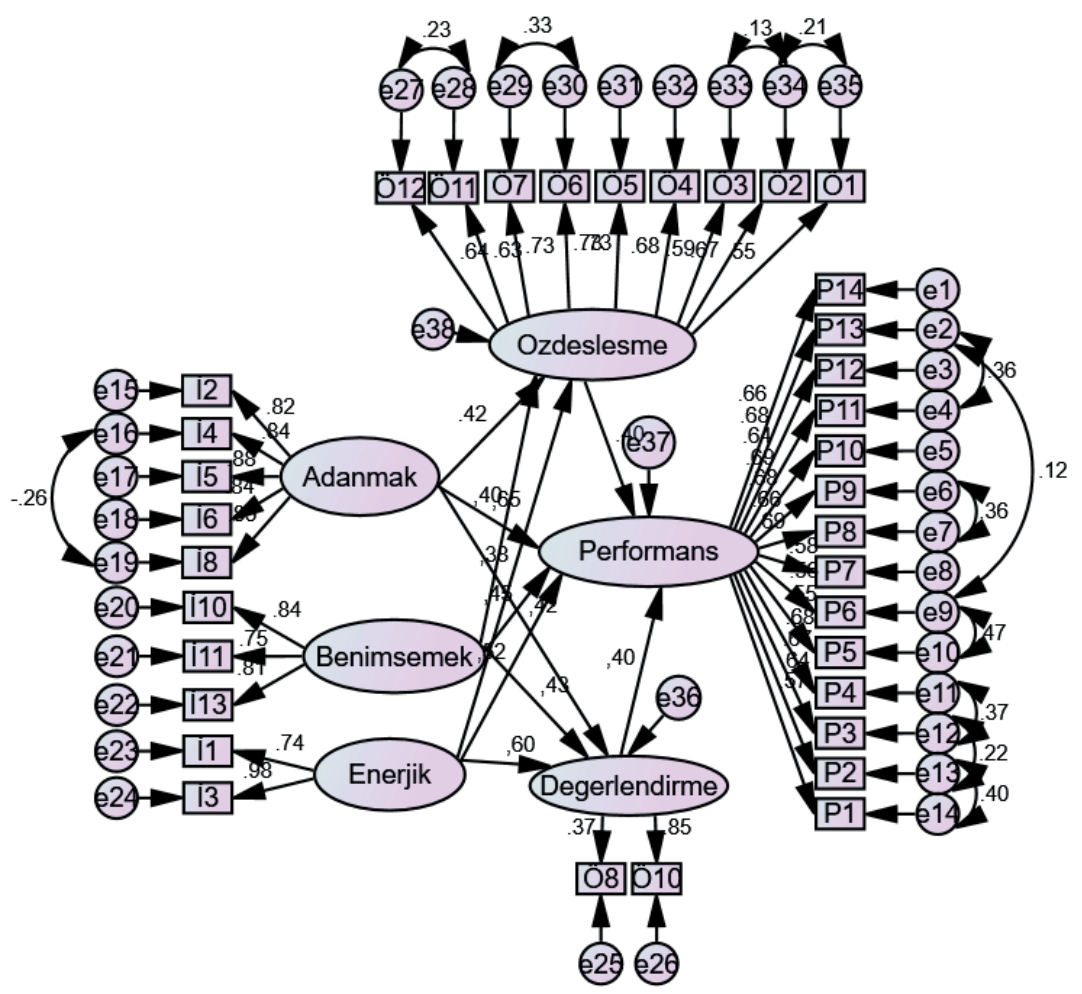

Şekil 3. Yapısal eşitlik modellemesi (YEM) yol analizleri 
Hipotezlere yönelik işe adanma, örgütsel özdeşleşme ile performans alg1s1 arasındaki ilişkinin test edildiği Yapısal Eşitlik Modeli test sonuçları Tablo 9'da verilmiştir. Test sonucuna göre 17 adet hipotezden, 11 adedi desteklenmiştir (Schermelleh-Engel, K., Moosbrugger, H., \& Müller, H., 2003: 23-74).

Tablo 9

Yapısal Eşitlik Modellemesi ile Yapılan Hipotez Testleri

\begin{tabular}{|c|c|c|c|c|}
\hline Hipotezler & Est. & S.E & $\mathbf{P}$ & Sonuç \\
\hline 1. "Adanma" ile "Özdeşleşme" arasında bir ilişki vardır. &, 110 & 021 & $* * *$ & Kabul. \\
\hline $\begin{array}{l}\text { 2. "Adanmak" ile "Değerlendirme" arasında bir ilişki } \\
\text { vardır. }\end{array}$ &, 218 & ,025 & $* * *$ & Kabul. \\
\hline $\begin{array}{l}\text { 3. "İşe Adanmak" ile "İş̧ören Performansı" arasında bir } \\
\text { ilişki vardır. }\end{array}$ & ,102 &, 018 & $* * *$ & Kabul. \\
\hline $\begin{array}{l}\text { 4. "İ̧ste Enerjik Olmak" ile "Özdeşleşme" arasında bir ilişki } \\
\text { vardır. }\end{array}$ & ,005 &, 021 & ,671 & Red. \\
\hline $\begin{array}{l}\text { 5. "İşte Enerjik Olmak" ile "Değerlendirme" arasında bir } \\
\text { ilişki vardır. }\end{array}$ & ,074 & ,026 &, 004 & Kabul. \\
\hline $\begin{array}{l}\text { 6. "İşte Enerjik Olmak" ile "İşgören Performans Algısı" } \\
\text { arasında bir ilişki vardır. }\end{array}$ & ,014 & 013 & 294 & Red. \\
\hline $\begin{array}{l}\text { 7. "İşi Benimsemek" ile "Özdeşleşme" arasında bir ilişki } \\
\text { vardır. }\end{array}$ &, 118 & 017 & $* * *$ & Kabul. \\
\hline $\begin{array}{l}\text { 8. "İşi Benimsemek" ile "Değerlendirme" arasında bir ilişki } \\
\text { vardır. }\end{array}$ & ,068 & ,028 &, 017 & Kabul. \\
\hline $\begin{array}{l}\text { 9. "İ̧si Benimsemek" ile "İşgören Performans Algısı" } \\
\text { arasında bir ilişki vardır. }\end{array}$ &, 122 & 020 & $* * *$ & Kabul. \\
\hline $\begin{array}{l}\text { 10. "Örgütsel Özdeşleşme" ile "İşgören Performansı" } \\
\text { arasında bir ilişki vardır. }\end{array}$ & ,409 & ,066 & $* * *$ & Kabul. \\
\hline $\begin{array}{l}\text { 11. "Değerlendirme" ile "İgö̈ren Performans Algısı" } \\
\text { arasında bir ilişki vardır. }\end{array}$ &,- 003 &, 045 & 940 & Red. \\
\hline $\begin{array}{l}\text { 12. Örgütsel özdeşleşmenin, işe adanma ile işgören } \\
\text { performans algısı arasında aracı değişken rolü vardır. }\end{array}$ & ,045 & ,017 &, 010 & Kabul. \\
\hline $\begin{array}{l}\text { 13. İşi değerlendirmenin, işe adanma ile işgören performans } \\
\text { algısı arasında aracı değişken rolü vardır. }\end{array}$ & ,089 &, 052 & ,005 & Kabul. \\
\hline $\begin{array}{l}\text { 14. Örgütsel özdeşleşmenin, işte enerjik olmak ile işgören } \\
\text { performans algısı arasında aracı değişken rolü vardır. }\end{array}$ & ,002 & ,023 & ,931 & Red. \\
\hline $\begin{array}{l}\text { 15. İşi değerlendirmenin, işte enerjik olmak ile işgören } \\
\text { performans algisı arasında aracı değişken rolü vardır. }\end{array}$ & ,006 & ,008 & ,930 & Red. \\
\hline $\begin{array}{l}\text { 16. Örgütsel özdeşleşmenin, işi benimsemek ile işgören } \\
\text { performans algısı arasında aracı değişken rolü vardır. }\end{array}$ &, 048 & ,030 &, 012 & Kabul. \\
\hline $\begin{array}{l}\text { 17. İşi değerlendirmenin, işi benimsemek ile işgören } \\
\text { performans algısı arasında aracı değişken rolü vardır. }\end{array}$ & ,006 &, 010 & ,883 & Red. \\
\hline
\end{tabular}

Tablo 10'da YEM modeli sonucunda ilişkili olan değişkenler arasındaki aracılık etkisinin varlığının doğrulanabilmesi için Sobel Testi ile sınanmıştır. Regresyon yöntemi kullanılarak yapılan testlerin sonucunda; "İşe Adanmışlığın" alt boyutu olan "Adanmak" boyutu ile "İşgören Performansı" arasında "Özdeşleşme” aracılık etkisi gösterdiği belirlenmiştir. Yine "Işe Adanmışlığın” 
alt boyutu olan "Adanmak" alt boyutu ile "İşgören Performansı" arasında "Örgütsel özdeşleşme" alt boyutlarından "Değerlendirme" boyutunun aracılık etkisi gösterdiği belirlenmiştir. Ayrıca "İşe Adanmışlığın" alt boyutlarından "Benimsemek" alt boyutu ile "İ̧̧ören Performansı" arasında "Örgütsel Özdeşleşme"nin alt boyutlarından "Özdeşleşme” alt boyutunun aracılık etkisi gösterdiği belirlenmiştir. Test sonucuna göre Tablo 10'da gösterilen hipotezlerdeki arac1lık rolü ilişkilerinin anlamlı olduğu ifade edilmektedir $(\mathrm{p}<0,05)$ (SchermellehEngel, K., Moosbrugger, H., \& Müller, H., 2003: 23-74; Sobel \& Michael, 1982; Sobel \& Michael, 1986; Akt.Y1lmaz ve Dalbudak, 2018:522-529).

Tablo 10

Sobel Testi Sonuçlart

\begin{tabular}{lccc}
\hline Hipotezler & $\begin{array}{c}\text { Test } \\
\text { İstatistiği }\end{array}$ & S.E. & p \\
\hline $\begin{array}{l}\text { 12. Örgütsel özdeşleşmenin, işe adanma ile işgören performans } \\
\text { algısı arasında aracı değişken rolü vardır. }\end{array}$ & 13,376 & 0,009 & 0,000 \\
$\begin{array}{l}\text { 13. İși değerlendirmenin, işe adanma ile işgören performans } \\
\text { algısı arasında aracı değişken rolü vardır. }\end{array}$ & 6,432 & 0,007 & 0,000 \\
$\begin{array}{l}\text { 16. Örgütsel özdeşleşmenin, işi benimsemek ile işgören } \\
\text { performans algısı arasında aracı değişken rolü vardır. }\end{array}$ & 13,389 & 0,011 & 0,000 \\
\hline
\end{tabular}

$(\mathrm{p}<0,05)$

\section{Genel Değerlendirme ve Sonuç}

Araştırmanın kapsamı; işgörenlerin işe adanmışlık düzeyleri ve örgütsel özdeşleşme ilişkisinin performans algılarına etkilerini belirlemeye yönelik bir araştırma olup, elde edilen bulguların özeti, araştırmacılara ve uygulayıcılara öneriler aşağıda sunulmuştur.

\section{Analizlere İlişskin Genel Değerlendirme}

"İşe Adanmışlık" ölçeğinin alt boyutlarından "Adanmak" ve "Benimsemek" boyutları ile "Cinsiyet" değişkeninin anlamlı bir ilişkisinin olduğu tespit edilmiştir. Ortalama değerlere bakıldığında "Erkek" katılımcıların "Kadın" katılımcılardan daha fazla ortalama değere sahip olduğu görülmektedir. Bu konuyla ilgi araştırmalarda iş alanına ve ülkelere göre çok farklı sonuçlara rastlanmakla birlikte, benzer bir araştırmada Swaminathan da (2009:10) erkeklerin adanmışlık algısının, kadınlara göre daha yüksek olduğunu tespit etmiştir. Bu konuyla ilgili literatürde birçok neden sıralanmıştır. Bunların başında kadınları bekleyen birçok rolün yanında annelik, eşlik vb. gibi ailevi rollerin olduğu gerçeğinin yattığı değerlendirilmektedir. 
İşe adanmışlık ölçeğinin alt boyutlarından "Enerjik Olmak" boyutunun "Medeni Durum" değişkeniyle anlamlı ilişkisinin olduğu belirlenmiştir. Ortalama değerlere bakıldığında "Evli” katılımcıların "Bekar" katılımcılardan daha fazla ortalama değere sahip olduğu görülmektedir. Benzer sonuca Kular ve arkadaşları (2008:12), Shukla ve arkadaşları (2015:70) ile Carlsen (2015:30) tarafından yapilmış çalışmalarda da ulaşılmıştır.

İşe adanmışlık ölçeğinin alt boyutlarından “Adanmak” boyutunun katılımcıların "Yaş" durumlarına göre anlamlı bir ilişkisinin varlığı belirlenmiştir. Araştırmada 56 ve üzeri yaş grubunun diğer gruplara göre daha yüksek adanma algısına sahip olduğu, en düşük puana sahip olan grubun ise 26-35 yaş grubu olduğu belirlenmiştir. Benzer bir sonuca öğretmenler üzerinde Turhan vd. (2012: 187188) tarafından yapılan araştırmada da ulaşılmış olup; 51 ve yaş üzerindeki öğretmenlerin adanma algılarının daha yüksek olduğu tespit edilmiştir. Ancak bu durumun sektörden, sektöre ve bölgeden, bölgeye farklılık göstereceği değerlendirilmektedir.

İşe adanmışlık ölçeğinin alt boyutlarından "Adanmak" ve "Enerjik Olmak" boyutlarının katılımcıların "Eğitim" durumlarıyla anlamlı ilişkisinin olduğu, Ortalama değerlere bakıldığında "Eğitim" seviyesi ile adanmanın ters orantılı olduğu anlaşılmaktadır. Bu konuda Celep vd. (2004:17) yaptığı çalışmada da öğretmenlerde eğitim seviyesi ile adanma algısının ters orantılı olduğunu tespit edilmiştir. Celep adanmışlıkla ilgili araştırmasında (2014:29-195); eğitim düzeyi arttıkça bireyin beklentisinin de aynı oranda artacağını, bununla birlikte bireyin beklentisi karşılanmadığında adanma algısının azalacağını, yani tükenmiş̧lik sendromuna gireceğini belirtmiştir. Literatürde bu konuyla ilgili farklı sonuçların da olduğu gözlemlenmiştir.

İşe adanmışlık ölçeğinin alt boyutlarından "Benimsemek" boyutunun katılımcıların kurumdaki "Çalışma Süreleri” ile anlamlı bir ilişki gösterdiği tespit edilmiştir.

İşe adanmışlık ölçeğinin alt boyutları olan "Adanmak" ve "Enerjik Olmak" boyutlarının katılımcıların kurumdaki çalışma durumlarına göre anlamlı bir ilişkisinin olmadığ 1 tespit edilmiştir. Genel olarak değerlendirildiğinde 0-10 y1l arasında kurumda çalışanların, diğerlerine nazaran daha fazla adanma algısı taşıdıkları ifade edilebilir. Okul yöneticilerine yönelik olarak Altunel (2015:165) tarafından yapılan benzer bir araştırmada, yöneticilerin mesleki kariyerlerinin 
ilk dönemlerinde kendilerini kurumuna karşı ispatlama sürecine girdikleri, bundan dolayı adanma seviyelerinin arttığı ancak belli bir noktadan sonra tükenmişlik sendromuna girdikleri ifade edilmiştir. Dolayısıyla mesleğinin ilk yıllarında çalışanların daha fedakâr ve adanma algılarıyla hareket etmelerinin normal olduğu değerlendirilmektedir.

Örgütsel özdeşlemenin alt boyutlarından "Özdeşleşme" ve "Değerlendirme" boyutlarının "Cinsiyet" değişkeniyle anlamlı bir ilişkisinin olmadığı belirlenmiştir.

Örgütsel özdeşlemenin alt boyutlarından "Özdeşleşme" ve "Değerlendirme" boyutlarının, katılımcıların "Medeni Durumlarıyla" anlamlı bir ilişkisinin olmadığı belirlenmiştir.

“Örgütsel Özdeşleşme” ölçeğinin alt boyutlarından "Değerlendirme" boyutunun katılımcıların "Yaş" durumları ile anlamlı bir ilişkisinin olduğu belirlenmiştir. LSD testi sonucuna göre, 56 ve üzeri yaş grubunun diğer gruplara göre daha yüksek puana sahip olduğu, en düşük puana sahip olan grubun ise 26-35 yaş grubu olduğu belirlenmiştir. Benzer bir araştırmada örgütle özdeşleşmeyi en çok gösteren yaş aralığının 50 yaş ve üzeri grubun olduğu tespit edilmiştir (Gürel, 2012: 55).

"Örgütsel Özdeşleşme" ölçeğinin alt boyutlarından "Değerlendirme" boyutunun katılımcıların "Eğitim" düzeyleri ile anlamlı bir ilişkisinin olduğu belirlenmiştir. LSD testi sonucuna göre, “İlköğretim Mezunları”nın diğer gruplara göre daha yüksek puana sahip olduğu, en düşük puana sahip olan grubun ise "Üniversite Mezunu" grup olduğu belirlenmiştir. Bu tabloya göre; ilköğretim düzeyinde eğitim görenlerin özdeşleşme algısının, diğerlerine göre daha yüksek olduğu ifade edilebilir. Bu konuda Gürel (2012:58) ve Bhattacharya (1995) yapmış oldukları araştırmada da benzer sonuca ulaşmıştır. Bhattacharya'da (1995) araştırmasında “Üniversite” ve "Lisansüstü” eğitim görenlerin örgütleriyle özdeşleşme seviyelerinin ters orantılı olduğunu tespit etmiştir.

“Örgütsel Özdeşleşme” ölçeğinin alt boyutlarından "Özdeşleşme” boyutunun katılımcıların "Kurumlarındaki Çalışma Süreleri” ile anlamlı bir ilişkisinin olduğu görülürken, diğer alt boyut "Değerlendirme" boyutunun "Kurumlarındaki Çalışma Süreleri” ile anlamlı bir ilişkisine rastlanmamıştır. Bu konuyla ilgili farklı kurumlarda, daha fazla sayıda katılımcının katılım sağlayacağ 1 araştırmalarda farklı sonuçlara ulaşılabileceği değerlendirilmektedir. Genelleme 
yapıldığında özdeşleşme boyutuna göre 0-5 yıl aralığında kurumda çalışanların özdeşleşme algılarının diğerlerine göre daha yüksek olduğu gözlemlenirken; aksine 16 yıl ve üzeri çalışanların özdeşleşme seviyelerinin diğerlerine göre daha düşük seyrettiği gözlemlenmiştir.

"Örgütsel Özdeşleşme" ölçeğinin alt boyutlarından "Özdeşleşme" ve "Değerlendirme” boyutlarının katılımcıların "Toplam Çalışma Süreleri” ile anlamlı bir ilişkisinin olduğu belirlenmiştir. Genel bir değerleme yapıldığında; toplam iş hayatında 0-15 yıl aralığında çalışmakta olan işgörenlerin, örgütleriyle özdeşleşme algılarının daha yüksek olduğu ifade edilebilir.

“İşgören Performans Algısı" ölçeğinin ortalama puanının "Cinsiyet" değişkeniyle ilişkisinin anlamlı olduğu görülmüştür. Ortalama değerlere bakıldığında "Erkek" katılımcıların "Kadın" katılımcılardan daha fazla performans algısına sahip olduğu görülmektedir. Bu sonucu destekleyen çalışmalar alanyazında mevcuttur. Büyükgöze ve Özdemir (2017:320) tarafından öğretmenler üzerine yapılan bir araştırmada ve bankacılık sektöründe Emhan vd. (2015:102) tarafindan yapılan başka bir araştırmada da benzer sonuçlar bulunmuştur.

“İşgören Performansı Algısı”"nın katılımcıların yaş durumlarıyla anlamlı bir ilişki göstermediği belirlenmiştir. Aynı konuda Ünal ve Günay (2016:11), Uslu (2014:82) ile Cengiz (2008:113); yaptıkları araştırmalarda performans algısı ile yaş değişkeni arasında bir ilişki bulunmadığını ifade etmişlerdir.

“İ̧̧gören Performans Algısı” ölçeğinin ortalamasının katılımcıların "Eğitim” durumlarına göre anlamlı bir ilişkisinin olduğu belirlenmiş̧tir. Ortalama değerlere göre; "İlköğretim" mezunlarının diğer gruplara nazaran daha yüksek puana sahip olduğu, en düşük puana sahip olan grubun ise "Lisansüstü" mezunu grup olduğu belirlenmiştir. Sonuç olarak; eğitim seviyesi ile performans algısının ters orantılı olduğu ifade edilebilir.

“İşgören Performans Algısı” ölçeğinin ortalamasının katılımcıların "Kurumlarındaki Çalışma Süreleri” ile anlamlı bir ilişkisinin olduğu belirlenmiştir. "İşgören Performansı" ortalama değerlerine bakıldığında 0-5 y1l arası çalışanların diğer gruplara göre daha yüksek ortalamaya sahip olduğu, en düşük performans algısı puanına sahip grubun ise 16-25 yıl arası çalışanlar olduğu belirlenmiştir.

“İşgören Performans Algısı” ölçeğinin katılımcıların “Toplam Çalışma Süresi” ile anlamlı bir ilişki varlığı belirlenmiştir. "İşgören Performans Algısı" 
sıra ortalama değerlerine bakıldığında toplam iş hayatında 26-35 yıl arası çalışanların, diğer gruplara göre daha yüksek bir ortalamaya sahip olduğu, bunu 0-10 yıl aralığında çalışan grup izlemekteyken; en düşük ortalamaya sahip grubun ise 16-25 yıl arası çalışanlar olduğu belirlenmiştir.

Değişkenlerin ilişkileri bakımından incelendiğinde; "Adanmak” ile "Örgütsel Özdeşleşme” arasında anlamlı bir ilişki olduğu görülmektedir. Bu konuda bezer bir çalışma yapan Kanten'in (2012: 216) araştırmasında da “İşe Adanma” ile “Örgütsel Özdeşleşme” arasında pozitif yönde anlamlı bir ilişki tespit edilmiştir. Karanika-Murray vd. (2015: 8-9) tarafindan yapılan çalışmada da örgütsel özdeşleşmenin, adanmışlıkla pozitif ilişkili olduğu sonucuna ulaşılmıştır.

“Adanmak" alt boyutu ile "Değerlendirme" alt boyutu arasında anlamlı bir ilişki olduğu araştırma sonuçlarına göre değerlendirilmektedir. Buradan da örgütle ilgili yapılan iç ve dış değerlendirmelerin, işgören adanmışlığında etkili olduğu değerlendirilmektedir.

“Adanmak” alt boyutu ile "İşgören Performans Algısı” arasında, pozitif ve anlamlı bir ilişki görülmüştür. Bu hipotez sonucunun daha önce yapılmış bazı araştırma sonuçlarıyla uyumlu olduğu görülmüştür Örneğin Bakker ve Bal'ın (2010) araştırmalarında, adanmış öğretmenlerin görev içi ve görev dışı işlere yönelik performans değerlendirmelerinde, yöneticilerinden daha yüksek puan almaları göstermektedir ki adanmış çalışanlar iyi çalışmakta ve fazladan bir şeyler yapma gayreti içindedirler. Bakker ve arkadaşlarının 144 çalışana yönelik yaptı̆̆ı anket uygulama sonucu da bu hipotezi desteklemiştir (Bakker vd., 2012: 557-560).

"İşte Enerjik Olmak" alt boyutu ile “Özdeşleşme” alt boyutu arasında anlamlı bir ilişki görülmemiştir. Bu çalışmada da analiz sonucunun bu hipotezi desteklememesine rağmen, Karanika-Murray vd. (2015: 8-9) tarafından İngiltere'de üç farklı organizasyonda toplam 177 personel ile yapılan çalışmada da örgütsel özdeşleşmenin, adanmışı̆̆ğı alt boyutları olan enerjik olmakla pozitif ilişkili olduğu sonucuna ulaşılmıştır.

“İşte Enerjik Olmak" alt boyutu ile "Değerlendirme" alt boyutu arasında, pozitif ve anlamlı bir ilişki görülmüştür. Örgütle ilgili olarak yapılan iç ve diş değerlendirmelerin, iş yaparken enerjik hissetmeyle bir ilişkisinin olduğu bu sonuca göre değerlendirilmektedir. 
"İşte Enerjik Olmak" alt boyutu ile "İşgören Performans Algısı" arasında, pozitif ve anlamlı bir ilişki görülmemiştir. Bu çalışmada analiz sonucunun bu hipotezi desteklememesine rağmen, benzeri bir araştırmada Bakker ve arkadaşlarının 144 çalışana yönelik yaptığı araştırmada enerjik olma boyutunun performans1 etkileyeceği ifade edilmiştir (Bakker vd., 2012: 562).

"İşi Benimsemek" alt boyutu ile "Örgütsel Özdeşleşme” alt boyutu arasında, pozitif ve anlamlı bir ilişki olduğu görülmüştür. Benzer şekilde bir araştırma yapan Riketta'nın (2004) araştırma sonucuna göre de örgütsel özdeşleşme ile işe benimseme (katılım) arasında pozitif bir ilişki olduğu tespit edilmiştir (Riketta, 2004:373).

"İşi Benimsemek" alt boyutu ile "Değerlendirme" alt boyutu arasında, pozitif ve anlamlı bir ilişki görülmüştür. Örgütle ilgili olarak yapılan değerlendirmelerin, işgörenin işini benimsemesiyle bir ilişkisinin olduğu değerlendirilmektedir.

“İşi Benimsemek” ile "İş̧gören Performansı" arasında pozitif ve anlamlı bir ilişki olduğu görülmüştür. Benzer bir araştırmada Brown ve Leigh (1996) tarafindan da işi benimsemenin, performansla pozitif ilişkisi olduğu tespit edilmiştir (1996:364).

“Örgütsel Özdeşleşme” ile "İşgören Performansı” arasında pozitif ve anlamlı bir ilişki olduğu görülmektedir. Örgütsel özdeşleşme ile performans ilişkisine dair bankacılık sektöründe yapılan bir araştırmada; örgütsel özdeşleşme ile iş performansı arasında anlamlı bir ilişki olduğu ve örgütsel özdeşleşmenin iş performansını pozitif şekilde etkilediği tespit edilmiştir (Turunç, 2010: 263). Karanika-Murray ve arkadaşları (2015:6) tarafindan yapılan çalışmada da örgütsel özdeşleşmenin, işgören performansı ile pozitif ilişkili olduğu ifade edilmiştir.

"Değerlendirme" ile "İşgören Performans Algısı" arasında pozitif ve anlamlı bir ilişki görülmemiştir. Bu sonuca göre örgütle ilgili olarak yapılan iç ve dış değerlendirmelerin işgörenin performans algısı ile bir ilişkisinin olmadığı değerlendirilmektedir.

“Özdeşleşme” alt boyutunun "Adanmak” alt boyutu ile "İşgören Performans Algısı” arasında aracı değişken rolünün olduğu görülmüştür.

"Değerlendirme" alt boyutunun "Adanmak" alt boyutu ile "İşgören Performans Algısı" arasında aracı değişken rolünün olduğu görülmüştür. 
“İşte Enerjik Olmak" algısı ile "İşgören Performans" algısı arasında “Özdeşleşme”nin aracı değişken rolünün olmadığı görülmüştür.

“İşte Enerjik Olmak" algısı ile "İşgören Performansı" algısı arasında "Değerlendirme”nin aracı değişken rolünün olmadığı görülmüştür.

“Özdeşleşme” alt boyutunun “Benimsemek” alt boyutu ile "İşgören Performans Algısı” arasında aracı değişken rolünün olduğu görülmüştür.

"Değerlendirme” alt boyutunun "Benimsemek” alt boyutu ile "İşgören Performans Algısı" arasında aracı değişken rolünün olmadığı görülmüştür.

\section{Araştırmacılar İçin Sonuç ve Öneriler}

Özellikle üzerinde henüz kavramsal mutabakat sağlanamamış olan adanmışlık, bağlılık ve sadakat gibi kavramların çoğu bizim kültürümüzde kullanılan kavramlar olmasına rağmen, alanyazında bu konuda ciddi bir karmaşa yaşandığ gözlemlenmektedir. Bu konuda referans alınan ulusal yazınların, referanslarındaki kavramların birbiriyle uyumlu olmalarına özen gösterilmelidir. Örneğin, "adanmak" ile ilgili makaleleri incelemek için Tez Merkezinden tarama yaptığımızda bu kavramın karşılığının yarıdan biraz fazlasının İngilizce "Engagement"olarak kullanıldığını, neredeyse yarıya yakınının “Commitment” kavramını, bir kısmının da "Dedicate" vb. kavramları esas aldıkları görülmüştür. Halbuki aynı taramayı "Bağlılık" olarak yaptığımızda araştırmaların tamamına yakınının "Commitment" kavramını kullandıkları görülmektedir. Bu konuda kitapları bulunan ve yurt dışında akademik eğitim görmüş uzmanlarla yapılan mülakat ve literatür taraması neticesinde; "Engagement ve Dedication" kavramlarının "Adanmak/Adanmışlık" olarak alınmasının, bununla birlikte "Commitment” kavramının "Bağlılık" olarak alınmasının daha doğru olacağı kanaati hasıl olmuştur. Bundan sonra adanmışlık ve bağlılık gibi konularda araştırma yapacak araştırmacıların bu kavram karmaşasının önüne geçmek için yazarların referans aldığı kaynaklardaki terimlere de dikkat etmeleri gerektiği görülmektedir.

$\mathrm{Bu}$ araştırmada kullanılan anket ölçeklerinin Amerika ve diğer gelişmiş ülkelerde geliştirilen ölçekler olması nedeniyle; değişkenlerin ölçülmesindeki hassasiyeti kültürel, etik ve ahlâki değerler ve farklılıklar açısından tam olarak ülkemizde yansıtamayacağı değerlendirilmektedir. Bu durumun önüne geçebilmek için ülkemize özgü milli ölçekler geliştirmenin araştırılması gereken önemli bir konu olduğu değerlendirilmektedir. 
Kişisel veriler, işe adanma, örgütsel özdeşleşme ve performans değişkenlerinden oluşan toplam 46 soruluk anket uygulaması için birçok kuruma (yaklaşık yazılı ve sözlü 52 kurum) müracaat edilmesine rağmen sadece dört kurum ve kuruluştan "uygundur" cevabı verilmiştir. Bunun en önemli nedeninin ise toplam 46 soru ve dört sayfadan oluşan anketin her ne kadar doldurma ortalaması 10 dakika olsa bile yetkililerin çalışanların vakit kaybına neden olabileceği önyargısıyla kabul edilmemiştir. Bundan sonraki araştırmacıların benzeri anket uygulamalarını mümkün olduğunca kısa ölçeklerle yapmalarının daha geniş katılımı sağlayacağı değerlendirilmektedir.

Anket sorularının 46 sorudan oluşmasının diğer bir sakıncası ise ankete gönüllü katılanların anketi bir an önce tamamlamak için anket sorularını tam okumadan, genelde aynı yöndeki şıkları doldurma temayülü gösterdikleri tespit edilmiştir. Bu durumu engellemek için de araştırmacılara anket sorularının sadeleştirilmesi ve sayısının azaltılması önerilmektedir.

Daha önceki araştırmaların çoğunun eğitim ve sağlık sektöründe uygulandığ1 tespit edilmiş ve daha önceki tavsiyelere uyularak öncelikle asker ve polisler üzerinde; ayrıca gönüllü çalışmalarıyla ön plana çıkan kuruluşlardan Türkiye Diyanet İşleri Başkanlığı ve Türk Kızılayı teşkilatlarında araştırma yapılmak istenmiş ancak geçtiğimiz olağanüstü dönemden dolayı gerekli izin alınamamıştır. Bundan sonra bu konuda araştırma yapacak araştırmacıların normal dönemlerde asker ve polisler ile gönüllü çalışmalarıyla göz önünde olan kuruluşlardan Türkiye Diyanet İşleri Başkanlığı ve Türk Kızılayı çalışanlarıyla araştırma yapması tavsiye edilmektedir.

Son olarak işe adanmış çalışanlar ordusu meydana getirmek için "ç̧alışanların, işlerini en önemli değerleri olarak algılamasını sağlayacak hususlar üzerine anket ve araştırmalar yapılmalı ve bu hususta genel öncelikler belirlenmelidir.

\section{Uygulayıcılar İçin Sonuç ve Öneriler}

Araştırmalardan çalışanların ancak \%20'sinin işine aktif adanmış, yaklaşık \%20'sinin ise adanmamış yani adanmışlık boşluğunda olduğu ve kalan yaklaşık \%60'lık bölümün ise tarafsız durumda olduğu anlaşılmaktadır. Bu kapsamda;

Adanmış olan \%20'lik kesimin tespit edilerek, emsal teşkil edecek şekilde onure edilmeleri ve işe devamlarının temin edilmesi sağlanmalıdır. 
Adanmışlık boşluğunda olan \%20'lik kesimin problem sahalarının tespit edilerek, problem sahalarına yönelik iyileştirme yapılmasıyla bu grubun da adanmalarının sağlanması hem performans hem de işgören devir hızı açısından ele alınmalıdır.

Tarafsız olan yaklaşık \%60’lık grubun adanmasını sağlamak amacıyla araştırmalarda tespit edilen; işin anlamı kavramak, özerklik, yükselme imkânı, sonucu bütüncül olarak görebilmek ve aidiyet gibi kavramlar, yönetim tarafından uygun metotlarla, hayata geçirilmelidir.

Araştırmada evli olan personelin, bekârlara nazaran adanma algılarının daha yüksek olduğu görülmektedir. Bu hususta uygulayıcılara, adaylar arasında bütün özelliklerinin eşit olduğu durumlarda, evli personelin tercih edilmesinin daha fazla verim sağlayacağı önerilebilir.

Araştırmada 56 ve üzeri yaş grubunun diğer gruplara göre daha yüksek adanma ve özdeşleşme algısına sahip olduğu tespit edilmiştir. Uygulayıcılara 56 ve üzeri yaş grubunun diğer gruplara göre daha yüksek adanma ve özdeşleşme algısı taşıdıkları ve bu grubun fedakarlık yapmaya en yatkın grup olduklarının değerlendirildiğinden bu grubu uygun iş ve pozisyonlarda değerlendirmeleri önerilmektedir.

Araştırmada ayrıca 26 ve 35 yaş aralığındaki çalışan grubunun, diğer gruplara göre daha düşük adanma ve özdeşleşme algısına sahip olduğu tespit edilmiştir. Bazı araştırmalara göre; 26-35 yaş aralığ 1 kariyer sürecinde "geçiş süreci" olarak ifade edilmektedir. Bu süreç gençlerin kendilerine kariyer için konum belirlemeye çalıştıkları bir süreç olması nedeniyle adanma ve özdeşleşmenin düşük seviyede çıkması normal olarak değerlendirilmektedir. Uygulayıcılara bu süreçteki kariyer belirsizliklerinin netleştirilerek, geçiş sürecinin kısaltılması önerilmektedir.

Araştırmada eğitim seviyesi ile adanma seviyesinin ters orantılı olduğu görülmektedir. Alanyazında da ifade edildiği gibi eğitim düzeyi arttıkça bireyin beklentisinin de aynı oranda artacağı, bununla birlikte bireyin beklentisi karşılanmadığında adanma ve özdeşleşme algısının azalacağı anlaşılmaktadır. $\mathrm{Bu}$ analiz tespitinden uygulayıcılara iki sonuç çıkmaktadır:

Bunlardan ilki, iş alanlarında istihdam planlaması esnasında kadro gereği eğitim düzeyi hangi seviyeyi gerektiriyorsa o düzeyde istihdam sağlanmalıdır. 
İkinci olarak ise personelin anayasal hakkı olan eğitim düzeyinin gelişimiyle birlikte, kariyer gelişiminin de sağlanması önerilmektedir. Aksi takdirde personelde tükenmişlik belirtileri görülmeye başlayacağı değerlendirilmektedir.

Özellikle yöneticilerin iletişim becerisi ve empati kabiliyeti yüksek, alanına hakim kimselerden olamaları sağlanmalıdır. Unutulmamalıdır ki örgütüyle özdeşleşmiş ve işine adanmış çalışanlar ordusu için ilk kademe yöneticilerinin çok önemli olduğu göz önünde bulundurulmalıdır.

Çalışanın değerli olduğunu hissettirmek için çalışanların alanlarıyla ilgili fikirleri sorulmalı ve kararlara katılmaları kolaylaştırılmalı ve yetki paylaşımı sağlanmalıdır.

Gönüllü olarak beklenenin ötesinde performans sergilemek olan adanmışlı̆̆ geliştirmek için örgütte gönüllü davranışların yapılmasına teşvik ve önderlik yapmalıdır.

Finansal Destek: Yazarlar bu çalışma için finansal destek almamışlardır. 


\section{Kaynakça/References}

Aktaş, H. ve Şimşek, E., (2014). Örgütsel sessizlik ile algılanan bireysel performans, örgüt kültürü ve demografik değişkenler arasındaki etkileşim. Akdeniz Üniversitesi Iktisadi ve İdari Bilimler Fakültesi Dergisi, 14(28), 24-52.

Altunel, A. T. (2015). Örgütsel güven düzeyi ile örgütsel adanmışlık düzeyi arasındaki ilişki: Bir araştırma. (Yayınlanmış Yüksek Lisans Tezi), İnönü Üniversitesi, Malatya.

Anttila, E. (2014). Components of organizational commitment-a case study consisting managers from Finnish Industrial Company, (Designated Master's Thesis), University of Tampere, Finland.

Attridge, M. (2009). Measuring and managing employee work engagement: A review of the research and business literature, Journal of Workplace Behavioral Health, 24(4), 383-398.

Aybas, M. (2014), Insan kaynakları uygulamalarının çalışanların işe adanmışlığı üzerindeki etkisi ve pozitif psikolojik sermayenin arac1 rolü konuya ilişkin bir araştırma, (Yayınlanmış Doktora Tezi), İstanbul Üniversitesi, İstanbul.

Bakker, A. B., Demerouti, E., \& Lieke, L. (2012). Work engagement, performance and active learning: The role of conscientiousness. Journal of Vocational Behavior, 80, 555-564.

Barlı, Ö. (2010). Davranış bilimleri ve örgütlerde davranış. Genişletilmiş ve Geliştirilmiş, 4.Baskı, Ankara.

Bhattacharya, C. B. (1995), Understanding the bond of identification: An investigation of its correlates among art museum members. Journal of marketing, 59(4), 46-57.

Bilgin, L. vd. (2011). Insan Kaynakları Yönetimi. (Ed. Ramazan Geylan) Anadolu Üniversitesi, Eskişehir.

Brown, S. P., \& Leigh, T. W. (1996). A new look at psychological climate and it's relationship to job involvement, effort, and performance. Journal of Applied Psychology, 81(4), 358-368.

Buchanan, B. (1974). Building organizational commitment: the socialization of managers in work organizations. Administrative Science Quarterly, 533-546.

Büyükgöze, H. ve Özdemir, M. (2017). İş doyumu ile öğretmen performansı ilişkisinin duygusal olaylar kuramı çerçevesinde incelenmesi. İnönü Üniversitesi Eğitim Fakültesi Dergisi, 18(1), 311-325.

Carlsen, J. J. (2015), An investigation of work engagement as a moderator of the relationship between personality and work outcomes, (Published Master Thesis), San Diego State University, San Diego, USA.

Celep, C. (2014). Eğitimde örgütlerinde örgütsel adanma, (2. Baskı), Nobel Yayınları, Ankara.

Cengiz, S. (2008). Otel İşletmelerinde Çalışanların Örgütsel Bağlllığının İşgören Performansı Üzerindeki Etkileri, (Yayımlanmış Master Tezi), Adnan Menderes Üniversitesi, Sosyal Bilimler Enstitüsü, Aydın. 
Chen, S. Y., Wu, W. C., Chang, C. S., Lin, C. T., Kung, J. Y., Weng, H. C., \& Lee, S. I. (2015). Organizational justice, trust, and identification and their effects on organizational commitment in hospital nursing staff. BMC Health Services Research, 15(1), 363.

Cüce, H. Güney, S. ve Tayfur, Ö. (2013). Örgütsel adalet algısı, örgütsel özdeşleşme ve iş tatmini arasındaki ilişkilere yönelik görgül bir araştırma. H. $\ddot{U}$. Iktisadi ve İdari Bilimler Fakültesi Dergisi, 13(1), 2013, 1-30.

Çöl, G. (2008). Algılanan güçlendirmenin işgören performansı üzerine etkileri. Doğuş Üniversitesi Dergisi, 9(1), 35-46.

Dick, R., Wagner, U., Stellmacher, J., \& Christ, O. (2004). The utility of a broader conceptualization of organizational identification: Which aspects really matter? Journal of Occupational and Organizational Psychology, 77(2), 171-191.

Dirin, İ. (2014), Algılanan Örgütsel Desteğin Örgütsel Özdeşleşme Üzerindeki Etkisi: TRB-2 Bölgesinde Uygulamalı Bir Araştırma, (Yayınlanmış Yüksek Lisans Tezi Tezi), Süleyman Demirel Üniversitesi, Isparta.

Emhan, A., Cura, F. ve Zincirkıran, M. (2015). İş memnuniyeti ve öğrenme kapasitesinin örgütsel performans üzerindeki etkisi: Bankac1lık sektöründe bir uygulama. ISGUC The Journal of Industrial Relations and Human Resources, 17(2), 92-108.

González-Romá, V., Schaufeli, W. B., Bakker, A. B., \& Lloret, S. (2006), Burnout and work engagement: Independent factors or opposite poles? Journal of vocational behavior, 68(1), 165-174.

Göktaş, K. (2004). Toplam Kalite Yönetimi ilkeleri uygulamalarının işletme performansi üzerine etkileri, (Yayımlanmamış Yüksek Lisans Tezi), Kadir Has Üniversitesi, İstanbul.

Gürel, H. (2012). The mediating role of individual responsibility on the relationship between corporate responsibility-organizational citizenship behavior and the role of corporate responsibility conceptions and organizational identification as moderator, (Deserted Doctoral Thesis), Marmara Üniversitesi, İstanbul.

Helvac1, M. A. (2002). Performans yönetimi sürecinde performans değerlendirmenin önemi. Ankara Üniversitesi Eğitim Bilimleri Fakültesi Dergisi, 35(1-2), 155-169.

İşcan, Ö. F. (2006). Dönüştürücü/etkileşimci liderlik algısı ve örgütsel özdeşleşme ilişkisinde bireysel farklılıkların rolü. Akdeniz Üniversitesi İdari ve İktisadi Bilimler Fakültesi Dergisi, 11, 160-177.

İşcan, Ö. F. ve Karabey,C. N. (2009). Örgütsel Özdeşleşme, (Editörler: Keser, A., G. Yılmaz ve Yürür, S.), Çalışma Yaşamında Davranış: Güncel Yaklaşımlar, Umuttepe Yayınları, Kocaeli.

Kahn, William A. (1990), Psychological conditions of personal engagement and disengagement at work. Academy of management journal, 33(4), 692-724.

Kanten, P. (2012), İşgörenlerde işe adanmanın ve proaktif davranışların oluşumunda örgütsel güven ile örgütsel özdeşleşmenin rolü, (Yayınlanmış Doktora Tezi), Süleyman Demirel Üniversitesi, Isparta. 
Karanika-Murray, Duncan, N., Pontes, H. M., \& Griffiths, M. D. (2015), Organizational identification, work engagement, and job satisfaction. Journal of Managerial Psychology, 30(8), 1019-1033.

Kılınç, E. ve Paksoy, H. M. (2017). Sağlık çalışanlarında performans algı düzeyinin bazı sosyo-demografik değişkenlere göre incelenmesi. Selçuk Üniversitesi Sosyal Bilimler Meslek Yüksekokulu Dergisi, 20(2), 151-159.

Koçel, T. (2011), İşletme yöneticiliği. (15. Baskı), Beta: İstanbul.

Köse, C. G., (2009). Örgütsel özdeşleşmenin çalışanların sürekli iyileştirme çabalarına katkısı: Bir araştırma, (Yayınlanmış Yüksek Lisans Tezi), İstanbul Üniversitesi Sosyal Bilimler Enstitüsü.

Mael, F., \& Ashforth, B. E. (1992), Alumni and their alma mater: A partial test of the reformulated model of organizational identification. Journal of Organizational Behavior, 13, 103-123.

Maslach, C., \& Leiter, M. P. (2008). Early predictors of job burnout and engagement. The Journal of applied psychology, 93(3), 498-512.

Mueller, R. O. (1996). Basic principles of structural equation modeling: An introduction to LISREL and EQS., New York: Springer.

Odabaş, Z. (2004). İş tatmini ve bireysel performans ilişkisi, (Yayınlanmamış Yüksek Lisans Tezi), Sakarya Üniversitesi, Sakarya.

Özdemir, H. Ö. (2007). Çalışanların Kurumsal Sosyal Sorumluluk Algılamalarının Örgütsel Özdeşleşme, Örgütsel Bağlılık ve İş Tatminine Etkısı: Opet Çalışanlarına Yönelık Uygulama, (Yayınlanmış Doktora Tezi), Marmara Üniversitesi, İstanbul.

Öztürk, Ü. (2006). Organizasyonlarda performans yönetimi. Sistem Yayıncılık: İstanbul.

Raza, M. I. (2015), MS thesis breach of psychological contract and its impact on organizational identification and organizational disidentification: Mediating role of perceived organizational support and moderating role of equity sensitivity, (Deserted Master Thesis), Mohammad Ali Jinnah University, Islamabad, Pakistan.

Riketta, M. (2005). Organizational identification: A Meta-Analysis. Journal of Vocational Behavior, 66(2), 358-384.

Rolf V. D., Wagner, U., Stellmacher, J., Christ, O., \& Tissington, P. A. (2005). To be (long) or not to be (long): Social identification in organizational contexts. Genetic, Social, and General Psychology Monographs, 131(3), 189-218.

Saks, A. M., \& Gruman, J. A. (2014). What do we really know about employee engagement? Human Resource Development Quarterly, 25(2), 155-182.

Schaufeli, W. B., \& Bakker, A. B. (2004). Utrecht work engagement scale, preliminary manual.

Schaufeli, W. B., \& Bakker, A. B. (2010). Defining and measuring work engagement: Bringing clarity to the concept, Work engagement: A handbook of essential theory and research, ISO 690, p.10-24. 
Schaufeli, W. B., \& Bakker, A. B. (2010). Defining and measuring work engagement: Bringing clarity to the concept, Work engagement: A handbook of essential theory and research, ISO 690, p.10-24.

Schaufeli, W. B., Bakker, A. B., \& Salanova, M. (2006). The measurement of work engagement with a short questionnaire: A cross-national study. Educational and psychological measurement, 66(4), 701-716.

Schermelleh-Engel, K., Moosbrugger, H., \& Müller, H., (2003). Evaluating the fit of structural equation models: Tests of significance and descriptive goodness-of-fit measures. Methods of psychological research online, 8(2), 23-74.

Shukla, S., Adhikari, B., \& Singh, V. (2015). Employee engagement-role of demographic variables and personality factors. Amity global HRM review, 5, 65-73.

Sı̆̆rı, Ü. ve Gürbüz, S. (2016). Örgütsel davranış. 3.Bask1, Beta Yayınları: İstanbul.

Soydan, T. (2014. Eğitim alaninda performans değerlendirme sisteminin geçerliği üzerine yönetici ve öğretmen görüşlerine dayalı bir araştırma. Ege Eğitim Dergisi, 13(1), 1-25.

Swaminathan, J., \& Ananth, A. (2009). Impact of demographic factors on employee engagement: a study with reference to vasan publications private limited, chennai, published in: GITAM. Journal of management, 9(2), 34-50.

Şehitoğlu, Y. ve Zehir, C. (2010), Türk kamu kuruluşlarında çalışan performansının, çalışan sessizliği ve örgütsel vatandaşlık davranışı bağlamında incelenmesi. Amme İdaresi Dergisi, 43(4), 87-110.

Turhan, M., Demirli, C. ve Nazik, G. (2012). Sınıf öğretmenlerinin mesleğe adanmışlık düzeyine etki eden faktörler: Elazığ örneği, Istanbul Ticaret Üniversitesi Sosyal Bilimler Dergisi, 11(1), 179-192.

Turunç, Ö. (2010). Organizasyonlarda kontrol algılamalarının örgütsel özdeşleşme ve iş performansına etkisi. C.Ü. İkisadi ve İdari Bilimler Dergisi, 11(1), 251-269.

Uslu, V. (2014), İşletmelerde iş güvenliği performansı ve iş güvenliği kültürü algılamaları arasındaki ilişki: eskişehir ili metal sektöründe bir araştırma, (Yayımlanmış Yüksek LisansTezi), Eskişehir Osmangazi Üniversitesi, Eskişehir.

Ünal, Ö. F. ve Günay, Z. (2016). Çalışanların algıladıkları performansları ile 360 derece performans değerleme arasındaki ilişki: Bir telekomünikasyon şirketi örneği. Çankırı Karatekin Üniversitesi İ̈BF Dergisi, 6(1), 273-289.

Yılmaz, V. ve Dalbudak, Z. İ. (2018), Aracı Değişken etkisinin incelenmesi: yüksek hızlı tren işletmeciliği üzerine bir uygulama, Uluslararası Yönetim İktisat ve Işletme Dergisi, 14(2), 517-534.

Yirik, Ş., Uslu, A., Sancar, M. F. ve Kutukız, D. (2016). Otel işletmelerinde örgütsel sessizlik ve örgütsel adalet ilişkisi: Antalya örneği. Yenifikir Dergisi, 16, 7-15. 


\section{İnternet Kaynakları/Electronic Resources}

Türk Dil Kurumu, Erişim adresi http://www.tdk.gov.tr

What's the Difference between Trait, State, and Behavioral Employee Engagement?, Erişim adresi https://www.decision-wise.com/ whats- the- difference- between- traitstate- and-behavioral-employee-engagement

The Five Keys of Employee Engagement, Erişim adresi http://www.decision-wise.com/ the-five-keys-of-employee-engagement

İşgücü İstatistikleri, Eylül 2018, Erişim adresi http://www.tuik.gov.tr.pdf

Türkiye'de Mesleki Görünüm Erişim adresi https://media.iskur.gov.tr/13497/turkiyedemesleki-gorunum.pdf 